Article

\title{
Abrasive Wear Resistance of Concrete in Connection with the Use of Crushed and Mined Aggregate, Active and Non-Active Mineral Additives, and the Use of Fibers in Concrete
}

\author{
Lenka Bodnárová ${ }^{1}\left(\right.$, Martin Ťažký ${ }^{1}$, Lucia Ťažká $^{1, *}{ }^{1}$, Rudolf Hela ${ }^{1}$, Ondřej Pikna ${ }^{1}$ \\ and Libor Sitek ${ }^{2}$ (D) \\ 1 Institute of Technology of Buildings Materials and Components, Faculty of Civil Engineering, \\ Brno University of Technology, Veveri 331/95, 60200 Brno, Czech Republic; bodnarova.1@fce.vutbr.cz (L.B.); \\ tazky.m@fce.vutbr.cz (M.T.); hela.r@fce.vutbr.cz (R.H.); pikna.o@fce.vutbr.cz (O.P.) \\ 2 Department of Material Disintegration, Institute of Geonics of the CAS, Studentska 1768, \\ 70800 Ostrava, Czech Republic; libor.sitek@ugn.cas.cz \\ * Correspondence: tazka.1@fce.vutbr.cz; Tel.: +42-06-0832-2698
}

Received: 28 October 2020; Accepted: 24 November 2020; Published: 27 November 2020

check for updates

\begin{abstract}
Virtually every concrete structure comes into contact with abrasive effects of flowing media or solids, which have a direct impact on the durability of concrete. An abrasive effect is most pronounced in transport or water management structures, and these structures are often designed for a significantly longer service life (usually 100 years). This research evaluates the influence of the filler component in terms of the type of aggregate and its mineralogical composition on concrete abrasion resistance. As part of the impact of the binder component, several concrete mixtures were produced using the same aggregate and maintaining the same strength class with the addition of different types of active and inert mineral additives. In other parts of the research, the effect of adding fiber reinforcement on the abrasion resistance of concrete was verified. Mutual connections and correlations in different age groups $(7,28$ and 90 days) were sought for all obtained results. The abrasion resistance of the composite was monitored by using standard procedures, especially using a Böhm device. It was found that for good abrasion resistance of concrete, it is not necessary to produce concretes with high strength classes using often expensive mineral additives (microsilica) and quality aggregates, but the maturation time of the composite and its microstructure plays an important role.
\end{abstract}

Keywords: concrete composite; abrasion; type of aggregate; mineral additives; fiber; durability; concrete strength

\section{Introduction}

Concrete as a composite material has been used for many years for its good formability during construction, good physical and mechanical parameters and especially due to its good durability in all branches of the construction industry. A significant possibility of variability of the composition of the concrete mixture enables the production of a composite of precisely given parameters corresponding to specific requirements. If the finished product is to meet the given requirements, it is necessary to know exactly the effect of individual components of the composite on the resulting parameters.

In addition to the surrounding environment, the durability of a concrete composite is affected by its composition and the resulting physical and mechanical parameters. For the correct design of a concrete mixture, it is important to know exactly the surrounding influences to which the composite will be exposed during its lifetime. According to EN $206+$ A1, these ambient conditions are 
classified on the basis of their environment class, e.g., as XC (Carbonization-induced corrosion) or XF (Corrosion caused by thawing and freezing) [1]. However, the abrasive effects of flowing media or solids can also be included among the aggressive effects of the surrounding environment. Moreover, the mentioned standard completely omits the environment in which the concrete is exposed to the effect of mechanical abrasion. In the Czech Republic, within the complementary standard CSN P 73 2404/Z1, this environment is defined as XM (wear resistance of concrete) [2]. However, this complementary standard also only defines the recommended strength class of concrete, the dose of binder and the water-cement ratio. To some extent, the design of a concrete composition for this environment can be described as the least studied type of design, although virtually every concrete structure comes into contact with abrasive effects. However, this abrasive effect is most evident in traffic or water management structures, and these structures are often designed for a significantly longer durability (most often 100 years) than in the case of conventional structures [3].

The common feature of these structures is especially the emphasis on a very good resistance of their surface layers to abrasion. This is the case whether it is a walking or running surface layer in traffic constructions or a surface layer exposed to the flow of liquid media (almost always in connection with entrained solid particles) in water management structures. Gradual degradation of this layer causes further subsequent degradation of the material, which results in a loss of static function and a decrease in material life.

Abrasive wear is caused by the friction of small, solid particles with a size of several units $\mathrm{mm}$ or even smaller with the surface layer of concrete, which is disturbed by this medium. As a result of the disturbed surface layer, the internal structure of the concrete is revealed, which in the event of an unsuitable composite composition can lead to an overall weakening of the material and a reduction in the required service life of the building. The mentioned traffic structures or larger expansion units of industrial areas are usually disturbed only through classical friction, which can be accompanied by a certain amount of liquid.

On the other hand, structural parts of water management structures such as a plunge pool or open slipway are often eroded and subsequently disturbed by cavitation, which is created by a fast-flowing liquid (often accompanied by abrasive particles). All these possible effects of abrasive action disrupting the surface layers of concrete, whether they are mobile structures or water structures, must be considered in the design of the structure itself [4,5]. An example of a case study where engineers took the abrasion of concrete in their designs into account is the ice shield design of Confederation Bridge in Canada, the longest bridge in the world that extends over ice covered water. These engineers provided recommendations for specifying and designing concrete mixes, and also suggested finishing practices that improve abrasion resistance [6]. Also, the author of another study deals with the effect of concrete mix design on the type of aggregate and type of mineral additives for wear resistance of concrete intended for railway structures (traffic structures). The work describes a specific influence of aggregate and mineral additives on abrasive resistance of concrete [7].

Some studies show that good concrete resistance is ensured by using a higher strength class, i.e., using a higher dose of cement, the addition of active mineral additive and a low water-cement ratio [8-10]. Although these theories show positive results, the microstructure of the composite must be taken into account. The low water-cement ratio and higher doses of binder components can result in excessive volume changes of the concrete composite during its maturation [11,12]. These excessive volume changes may further result in the formation and development of micro cracks $[13,14]$. Each micro defect then becomes dangerous from the point of view of breaking the surface layer of the composite, which is in direct contact with the aggressive medium or is directly abrasively stressed. These micro defects appear to be very dangerous in water management structures, where they can result in a total loss of structural stability [15].

This comprehensive research aims to clarify the specific impact of individual components of concrete composite on its resistance to abrasion. Thanks to the precise clarification of the influence of input raw materials on the resistance of the final product, it is possible to directly apply acquired 
knowledge in practice and thus produce concrete mixtures for XM (according to the legislation in the Czech Republic, which refers to an environment in which the concrete is exposed to the effect of mechanical abrasion) environments with a long service life.

The purpose of this research is to provide a comprehensive picture of the impact of the basic components of the concrete composite on its resulting resistance to mechanical abrasion. The goal is to evaluate the impact of the different types of filler components, crushed vs. mined aggregate, binder component from the point of view of using active and non-active additives, added basalt, polypropylene fibers and the resulting mechanical parameters of the composite, which are related with concrete wear resistance. Base on the obtained conclusion, it is possible to clearly define the mechanisms by which it is possible to increase the resistance of the material to abrasion wear.

\section{Influence of Aggregate on the Resistance of Concrete to Mechanical Abrasion}

The aggregate occupies the largest part of the concrete composite and forms its solid skeleton, which is connected by a binder component. In the first part of the experiment, the influence of this most voluminous component of the concrete composite on its resistance to mechanical abrasion was verified. The influence of the used type of aggregate was evaluated from the point of view of its production (mined vs. crushed), its mineralogy and physical-mechanical parameters.

The selection of individual aggregates was based on a portfolio of the most common types of aggregates, on the basis of their origin and occurrence in the Czech Republic. Sedimentary rocks in the Czech Republic include surface-mined fluvial rocks or offal rocks occurring on the confines of sedimentary and metamorphic rocks (but these are crushed rocks). From this category, we chose Zabcice. From the group of igneous rocks on the confines of metamorphic rocks, we chose granodiorite rocks as a representative rock type-the Olbramovice aggregate. These rocks are found in the Czech Republic as orthorhombic rocks and the most common types are pure igneous amphibolite or balastandesit; we chose a representative type of rocks called Zelesice rocks. Three types of aggregate were selected for the experiment. All of the aggregates are produced in the Czech Republic. The first case involved a sedimentary fluvial psammitic rock from the Zabcice locality, which was obtained through opencast mining. Natural crushed aggregates from the localities of Zelesice and Olbramovice were also used. In both cases, they were crushed aggregates and their grains were sharp-edged and rather irregular in shape. Crushed aggregate from the Zelesice locality is a deep igneous rock of the amphibolite type, and the crushed aggregate Olbramovice is a metamorphic rock of the granodiorite type. All of the aggregates met the requirements of standards for aggregates for concrete production according to EN $12620+$ A1 and EN 13242 for aggregates for civil engineering and infrastructure purposes [16,17].

\subsection{Experiment of Influence of Aggregate on the Resistance of Concrete to Mechanical Abrasion}

The individual types of aggregates and their shapes are shown in Figure 1. The exact mechanical parameters of the used aggregates were supplied by their manufacturers and further verified by means of several performed tests. The basic tests that can directly indicate the resistance of aggregates to mechanical abrasion include the test for determining the resistance to crushing by using the Los Angeles method in accordance with EN 1097-2 [18]. This test was performed in an experiment together with the determination of density of aggregates and water absorption in accordance with EN 1097-6 [19], sieve analysis in accordance with EN 9331 [20] and for coarse aggregates together with the determination of the grain shape-shape index in accordance with EN 933-4 [21]. The results are shown in Table 1. 


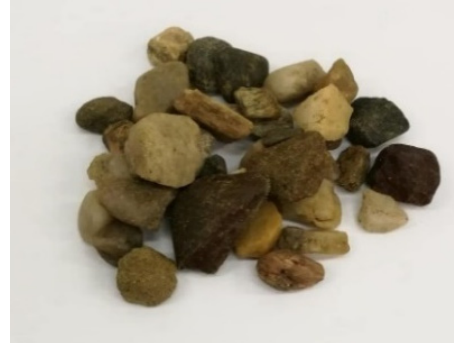

(a)

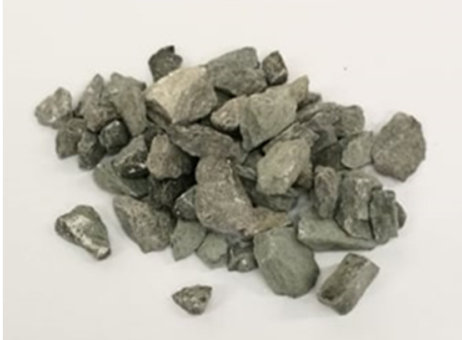

(b)

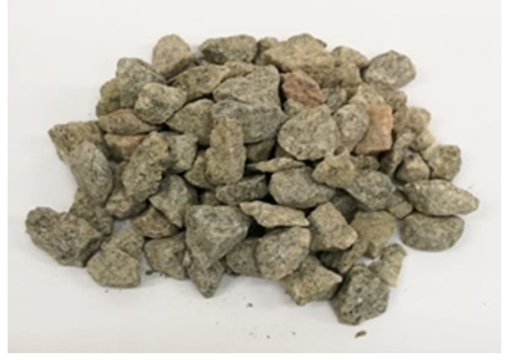

(c)

Figure 1. Used types of aggregates: (a) mined aggregate psammite, (b) crushed aggregate amphibolite, (c) crushed aggregate granodiorite.

Table 1. Parameters of used aggregates.

\begin{tabular}{|c|c|c|c|c|c|c|c|c|}
\hline Petrography & \multicolumn{3}{|c|}{ Psamitic Fluvial } & \multicolumn{3}{|c|}{ Amphibolite } & \multicolumn{2}{|c|}{ Granodiorite } \\
\hline Fraction $(\mathrm{mm})$ & $0-4$ & $4-8$ & $8-16$ & $0-4$ & $4-8$ & $8-16$ & $4-8$ & $8-16$ \\
\hline Type & \multicolumn{3}{|c|}{ mined } & \multicolumn{3}{|c|}{ crushed } & \multirow{2}{*}{\multicolumn{2}{|c|}{$\begin{array}{c}\text { Crushed } \\
\text { Olbramovice } \\
(\mathrm{CZ})\end{array}$}} \\
\hline Locality & \multicolumn{3}{|c|}{ Zabcice (CZ) } & \multicolumn{3}{|c|}{ Zelesice (CZ) } & & \\
\hline Density $\left(\mathrm{Mg} / \mathrm{m}^{3}\right)$ & 2.69 & 2.60 & 2.56 & 2.96 & 2.96 & 2.96 & 2.64 & 2.63 \\
\hline Water absorption (\%) & 1.2 & 1.1 & 0.9 & 0.6 & 0.9 & 0.7 & 0.5 & 0.6 \\
\hline Grain category (-) & GF85 & \multicolumn{2}{|c|}{ GC85/20 } & GF85 & \multicolumn{2}{|c|}{ GC85/20 } & \multicolumn{2}{|c|}{ GC85/20 } \\
\hline Fine particle content (\%) & 1.2 & 0.6 & 0.3 & 1.4 & 0.3 & 0.6 & 0.4 & 0.6 \\
\hline Shape index $(\%)$ & - & 12 & 20 & - & 28 & 33 & 32 & 23 \\
\hline Crush resistance-LA (-) & - & \multicolumn{2}{|c|}{40} & - & \multicolumn{2}{|c|}{18} & \multicolumn{2}{|c|}{29} \\
\hline
\end{tabular}

The following aggregates were used for this part of the experiment:

- Psammite-fractions $0-4 \mathrm{~mm}, 4-8 \mathrm{~mm}$ and $8-16 \mathrm{~mm}$,

- Amphibolite-fractions 0-4 $\mathrm{mm}, 4-8 \mathrm{~mm}$ and 8-16 $\mathrm{mm}$,

- Granodiorite-fractions $4-8 \mathrm{~mm}$ and $8-16 \mathrm{~mm}$.

The performed analyses clearly demonstrate that the shape index of mined aggregates is significantly lower than for crushed aggregates. Although this parameter may not have any connection from the point of view of abrasion resistance of the resulting concrete composite, some research studies point to the fact that the quality incorporation of aggregates (transit zone) creates an important aspect of the overall abrasion resistance of the composite. This fact is attributed to the reduction of the risk of loss of cohesion between the aggregate grain and the cement stone, which would result in the formation of a micro defect [22]. A higher specific surface area of the aggregate grain, which is often associated with a higher value of the shape index (especially in the case of crushed aggregates), creates a larger area for a quality connection of this grain and cement stone [23]. However, other studies state that due to the higher surface area of the aggregate grains, a higher water-cement ratio is needed to maintain the required degree of consistency of the concrete mixture, which can adversely affect the transit zone of the aggregate grains. Cement putty in the area of the transit zone always reaches a higher water-cement ratio due to water sticking to the surface of the aggregate grain, which can lead to its micro defects [24].

The results of the resistance of grains to crushing obtained using the Los Angeles method point to significantly higher values for mined sediment-type aggregate. All of these facts were assessed further in terms of the effect on the resistance of the concrete composite itself to mechanical abrasion.

To determine the impact of aggregate on the resistance of concrete to mechanical abrasion, several formulas were designed in accordance with the EN 206 + A1 and CSN EN 73 2404/Z1 standards for the XM3 environment. From the point of view of the strength class, concretes must meet class $C$ 35/45. In the experiment, all concretes were designed with a smooth grading curve and a maximum grain size of $16 \mathrm{~mm}$. This resulting grading curve of the aggregate mixture can be seen in Figure 2 . 
The design of the same grading curve for all formulas was chosen with regard to the fact that the only different parameter from the point of view of the composite filler was the type of aggregate used and so that its influence could be precisely determined. In addition, the possibility of using small crushed amphibolite aggregate with a fraction of $0-4 \mathrm{~mm}$ to improve the abrasion resistance of the composite was verified in the experiment. Due to the unsuitable granulometry of small crushed aggregates for the production of concrete mixtures intended for ready-mixed concrete, this aggregate was mixed in a volume ratio of $50 \%: 50 \%$ with small mined aggregate.

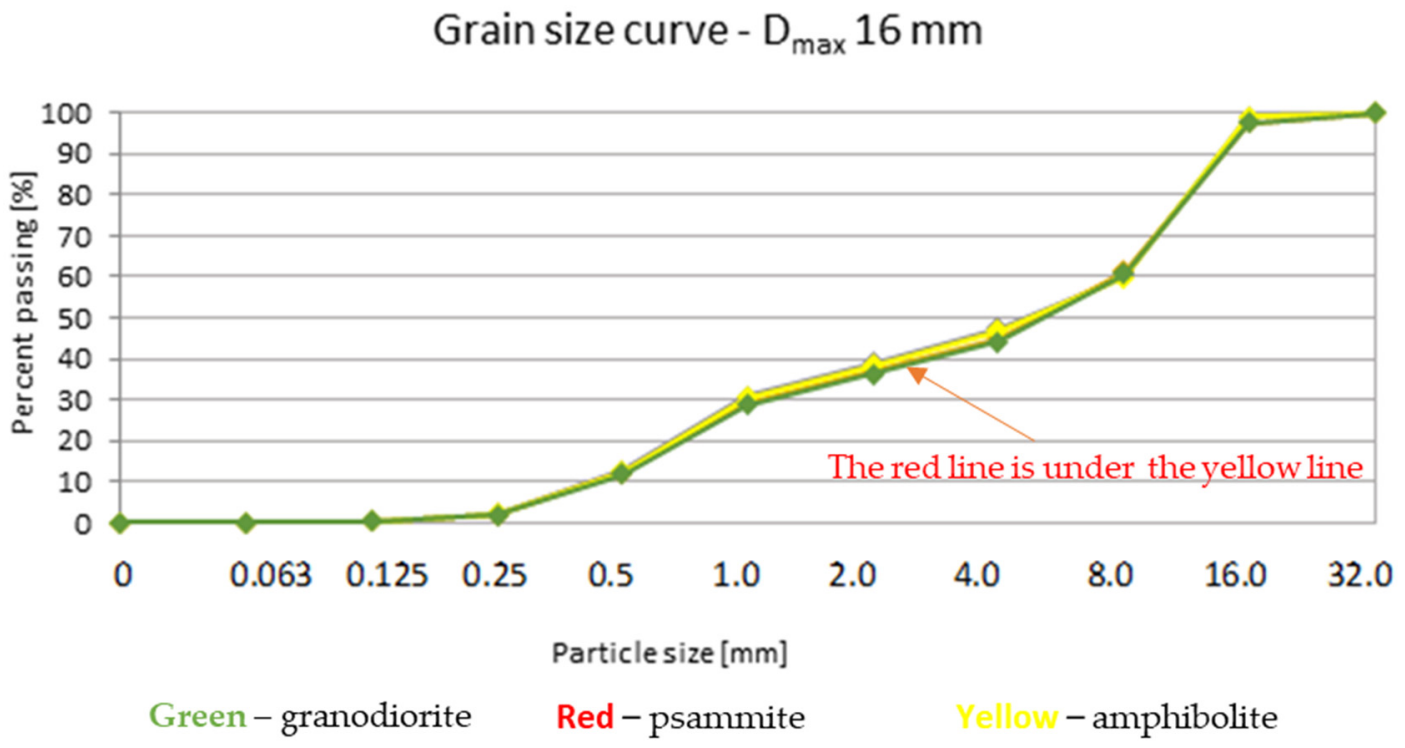

Figure 2. Resulting grading curves of aggregate mixtures.

A constant amount of CEM I $42.5 \mathrm{R}$ cement from the Mokra cement plant, which is part of the Heidelberg Group in the Czech Republic, was used for the production of concrete. The total calculation of the overall composition of the concrete mixture was based on the equation of absolute volumes, and the amounts of water and superplasticizer were chosen with regard to achieving workability of a fresh concrete mixture by using the cone slump method for class S4 according to EN 12350-2 [25]. A liquid superplasticizer from MC Bauchemie based on yellow-brown polycarboxylate ether with a density of $1060 \mathrm{~kg} / \mathrm{m}^{3}$ was used for the experiment. An overview of the composition of individual mixtures is given in Table 2.

Table 2. Composition of concrete mixtures.

\begin{tabular}{cccc}
\hline Raw Material/Designation & PSM & AMP & GRN \\
\hline CEM I 42.5 R (kg) & 335 & 335 & 335 \\
0-4 Psamite (\%) & 45.9 & 23.9 & 47.5 \\
0-4 Amphibolite (\%) & - & 24.2 & - \\
4-8 Psamite (\%) & 13.4 & - & - \\
4-8 Amphibolite (\%) & - & 12.9 & - \\
4-8 Granodiorite (\%) & - & - & 11.2 \\
8-16 Psamite (\%) & 40.7 & - & - \\
8-16 Amphibolite (\%) & - & 39.0 & - \\
8-16 Granodiorite (\%) & - & - & 41.3 \\
Water (kg) & 165 & 175 & 170 \\
Superplasticizer (\%) of $\mathrm{m}_{\mathrm{c}}{ }^{*}$ & 0.85 & 1.10 & 1.00 \\
\hline${ }^{*}$ Note: $\mathrm{m}_{\mathrm{c}}$-amount of cement.
\end{tabular}


Verification of Properties of Designed Concretes

For fresh concretes, the density in the fresh state was determined in accordance with EN 12350-6 [26] and the degree of consistency was determined using the cone slump method in accordance with EN 12350-2 [25] within 5 min of production. The results of these tests are given in Table 3.

Table 3. Properties of fresh concrete (FC).

\begin{tabular}{cclc}
\hline Parameter/Designation & PSM & AMP & GRN \\
\hline Density $\left(\mathrm{g} / \mathrm{m}^{3}\right)$ & 2330 & 2500 & 2360 \\
Consistency by slump $(\mathrm{mm})$ & 170 & 160 & 160 \\
\hline
\end{tabular}

It is clear from the obtained results that the density of fresh concrete depends mainly on the density of the aggregate used. In the experiment, amphibolite aggregate noticeably reached the highest density, which is also evident from the densities of fresh concrete. The results show that with a suitable mixing ratio of fine crushed and fine mined aggregate, a concrete mixture with a degree of consistency that is up to $\mathrm{S} 4$ can be produced, although it was necessary to slightly increase the water-cement ratio and the dose of superplasticizer to achieve this.

Basic mechanical and physical parameters were assessed on hardened concrete after 7, 28 and 90 days. For the strength parameters, the compressive strength in accordance with EN 12 390-3 [27], flexural strength at four-point distribution in accordance with EN 12 390-5 [28] and tensile strength of concrete surface layers in accordance with CSN 731318 [29] were monitored. The density of hardened concrete was also determined in each age of the samples in accordance with EN 12390 6 [30]. The samples were stored in an aqueous environment with a constant temperature of $20 \pm 2{ }^{\circ} \mathrm{C}$ throughout the maturation.

In addition to these basic mechanical and physical parameters, durability parameters were also determined for the tested samples at 28 and 90 days (MC), which are directly related to their resistance to mechanical abrasion. These tests include the determination of the watertightness of concrete to grade HV 8 according to the regulation of the Directorate of Waterways in the Czech Republic [31]. This test consists in the ability of concrete to withstand a water pressure of $400 \mathrm{kPa}$ for the first $24 \mathrm{~h}$ and then $800 \mathrm{kPa}$ for a further $48 \mathrm{~h}$. After the test, the test specimen is broken perpendicular to the action of the water pressure and the maximum leakage depth is determined. Furthermore, the total water absorption of concrete was determined in accordance with CSN 731316 [32]. These parameters, as well as the tensile strength of the surface layers of concrete, may be directly related to the resistance of concrete to mechanical abrasion. The abrasion resistance itself was tested in dry conditions using a Böhm's device (Figure 3) in accordance with the normative procedure CSN 731324 [33] for determining the abrasion of concrete and in accordance with EN 13 892-3 [34] for determining the abrasion of screed materials. The difference between the individual test procedures was given by the number of performed test cycles and the evaluation of the monitored parameter. The method of preparation and the size of the test specimens were identical in both standard tests.

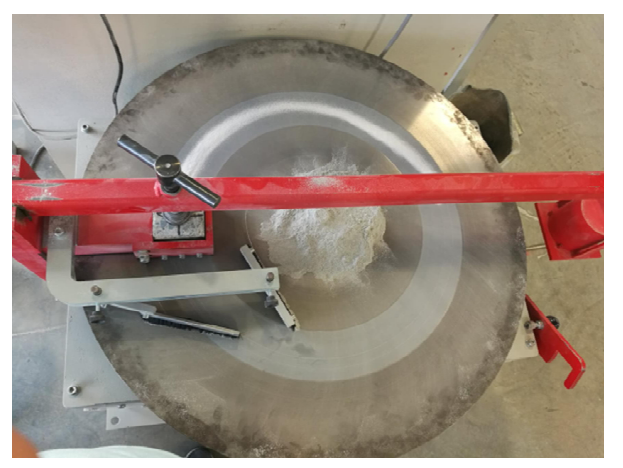

Figure 3. Böhm's device for determining the resistance of concrete to mechanical abrasion. 
In the first procedure in accordance with CSN 73 1324, the number of test cycles was set at 20 and the evaluation involved the percentage weight loss of the specimen. In the second case in accordance with EN 13892-3, the number of test cycles was 16 and the result of the test was a reduction in the volume of the test specimens given in $\mathrm{cm}^{3} / 50 \mathrm{~cm}^{3}$. The results of this test procedure are useful for eliminating the different densities of the test specimens. The results of all the strength, physical and durability parameters are given in Tables 4 and 5 .

Table 4. Mechanical and physical parameters of tested concretes.

\begin{tabular}{|c|c|c|c|c|c|c|c|c|c|c|}
\hline \multirow{2}{*}{\multicolumn{2}{|c|}{ Parameter/Designation }} & \multicolumn{3}{|c|}{ PSM } & \multicolumn{3}{|c|}{ AMP } & \multicolumn{3}{|c|}{ GRN } \\
\hline & & Mean & SD & $\mathrm{CV}$ & Mean & SD & $\mathrm{CV}$ & Mean & SD & $\mathrm{CV}$ \\
\hline \multirow{3}{*}{ Density $\left(\mathrm{kg} / \mathrm{m}^{3}\right)$} & 7 days & 2320 & 5 & 0.2 & 2500 & 5 & 0.2 & 2370 & 8 & 0.3 \\
\hline & 28 days & 2340 & 0 & 0.0 & 2520 & 8 & 0.3 & 2360 & 5 & 0.2 \\
\hline & 90 days & 2340 & 8 & 0.4 & 2520 & 5 & 0.2 & 2350 & 0 & 0.0 \\
\hline \multirow{3}{*}{$\begin{array}{l}\text { Compressive } \\
\text { strength (MPa) }\end{array}$} & 7 days & 21.8 & 0.5 & 2.3 & 43.1 & 0.6 & 1.3 & 31.1 & 0.2 & 0.7 \\
\hline & 28 days & 51.2 & 0.2 & 0.3 & 55.7 & 0.5 & 0.9 & 55.5 & 0.2 & 0.4 \\
\hline & 90 days & 60.0 & 0.5 & 0.8 & 57.5 & 0.6 & 1.0 & 64.0 & 0.4 & 0.7 \\
\hline \multirow{2}{*}{$\begin{array}{c}\text { Flexural strength } \\
(\mathrm{MPa})\end{array}$} & 28 days & 5.0 & 0.1 & 2.8 & 6.2 & 0.2 & 3.3 & 5.9 & 0.1 & 0.8 \\
\hline & 90 days & 5.5 & 0.1 & 2.3 & 7.3 & 0.2 & 2.3 & 6.7 & 0.1 & 1.9 \\
\hline \multirow{2}{*}{$\begin{array}{c}\text { Tensile strength of } \\
\text { surface layers (MPa) }\end{array}$} & 28 days & 1.95 & 0.07 & 3.72 & 2.33 & 0.09 & 3.85 & 2.35 & 0.07 & 3.35 \\
\hline & 90 days & 2.09 & 0.03 & 1.35 & 2.63 & 0.02 & 0.65 & 2.78 & 0.09 & 2.92 \\
\hline
\end{tabular}

Note: SD—Standard deviation, CV—coefficient of variation (\%).

Table 5. Results of durability parameters of tested concretes.

\begin{tabular}{|c|c|c|c|c|c|c|c|c|c|c|}
\hline \multirow{2}{*}{\multicolumn{2}{|c|}{ Parameter/Designation }} & \multicolumn{3}{|c|}{ PSM } & \multicolumn{3}{|c|}{ AMP } & \multicolumn{3}{|c|}{ GRN } \\
\hline & & \multirow{2}{*}{$\begin{array}{c}\text { Mean } \\
22\end{array}$} & \multirow{2}{*}{$\begin{array}{l}\text { SD } \\
2.5\end{array}$} & \multirow{2}{*}{$\begin{array}{c}\mathrm{CV} \\
11.5\end{array}$} & \multirow{2}{*}{$\begin{array}{c}\text { Mean } \\
14\end{array}$} & \multirow{2}{*}{$\begin{array}{l}\mathrm{SD} \\
1.7\end{array}$} & \multirow{2}{*}{$\begin{array}{c}\text { CV } \\
11.9\end{array}$} & \multirow{2}{*}{$\begin{array}{c}\text { Mean } \\
12\end{array}$} & \multirow{2}{*}{$\begin{array}{l}\text { SD } \\
2.5\end{array}$} & \multirow{2}{*}{$\begin{array}{l}\text { CV } \\
21.4\end{array}$} \\
\hline Concrete watertightness & 28 days & & & & & & & & & \\
\hline$(\mathrm{mm})$ & 90 days & 18 & 1.6 & 9.1 & 8 & 1.3 & 16.3 & 9 & 0.8 & 9.1 \\
\hline \multirow{2}{*}{ Water absorption (\%) } & 28 days & 6.7 & 0.1 & 2.1 & 6.4 & 0.08 & 1.3 & 6.3 & 0.13 & 2.0 \\
\hline & 90 days & 6.4 & 0.1 & 2.2 & 6.0 & 0.09 & 1.6 & 6.1 & 0.0 & 0.8 \\
\hline \multirow{2}{*}{$\begin{array}{l}\text { Determination of abrasion } \\
\text { according to EN } 13892-3 \\
\left(\mathrm{~cm}^{3} / 50 \mathrm{~cm}^{3}\right)\end{array}$} & 28 days & 13.35 & 0.08 & 0.61 & 11.40 & 0.11 & 0.95 & 13.65 & 0.11 & 0.79 \\
\hline & 90 days & 12.70 & 0.13 & 0.98 & 12.65 & 0.09 & 0.67 & 12.65 & 0.04 & 0.32 \\
\hline \multirow{2}{*}{$\begin{array}{c}\text { Determination of concrete } \\
\text { abrasion according to CSN } \\
731324(\%)\end{array}$} & 28 days & 5.80 & 0.09 & 1.47 & 5.10 & 0.08 & 1.60 & 6.10 & 0.05 & 0.77 \\
\hline & 90 days & 4.70 & 0.13 & 2.65 & 4.10 & 0.08 & 1.99 & 4.20 & 0.17 & 4.05 \\
\hline
\end{tabular}

Note: SD—Standard deviation, CV-coefficient of variation (\%).

\subsection{Discussion of Results}

From the results of the mechanical parameters of the tested formulas, it can be said that after 28 days of standard maturing, all concretes show comparable compressive strength and the results of abrasion resistance should not be directly dependent on this parameter. The comparison of the increase in the compressive strength of individual formulas can be evaluated as being interesting. With crushed aggregate amphibolite, it can be seen that its compressive strength does not change much after 7 days. On the other hand, in the case of the lowest quality mined aggregate psammite type, a significant increase in strength could be seen after up to 90 days. This fact can probably be attributed to the transit zone between cement stone and aggregate grains, the influence of which on the compressive strength of concrete is probably most pronounced in the early days of concrete maturation. The results of the tensile strength of the surface layers of concrete also correspond to this statement, where the values of both formulas with crushed aggregate show significantly higher values compared to the formula with mined aggregate. This fact corresponds to the research mentioned in the introduction and to claims that crushed aggregate with a larger measuring surface allow it to have 
better incorporation into the concrete matrix, which has a direct effect on the mechanical parameters of concrete. The following graphs in Figure 4 are focused on a comparison of the selected mechanical parameters and abrasion resistance of concrete. In the same way, the dependence of watertightness and water absorption of concrete on its resistance to mechanical abrasion was evaluated. From the results of these durability parameters, it is clear that they are directly affected by the properties of the aggregate used, particularly its grain water absorption. The assessment of individual monitored parameters concerning the abrasion resistance of concrete is shown in Figures 4 and 5 .

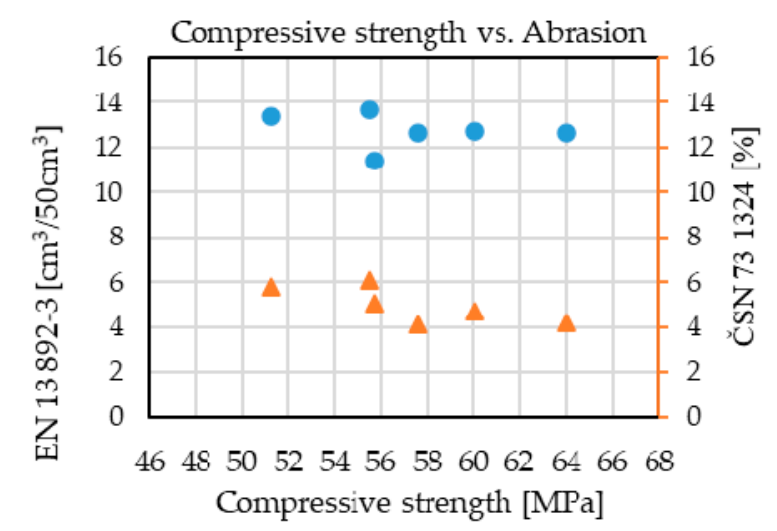

(a) •EN 13 892-3 $\Delta$ CSN 731327

Tensile strength vs. Abrasion

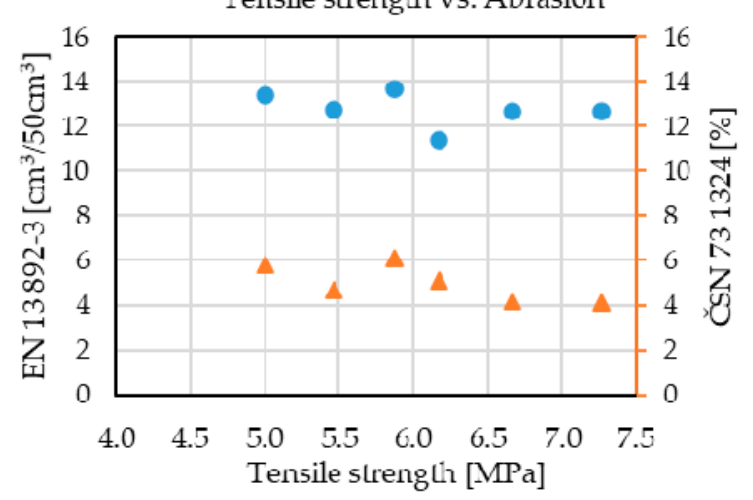

(b) • EN 13 892-3 $\Delta$ CSN 731327

Tensile strength of surface layers vs.

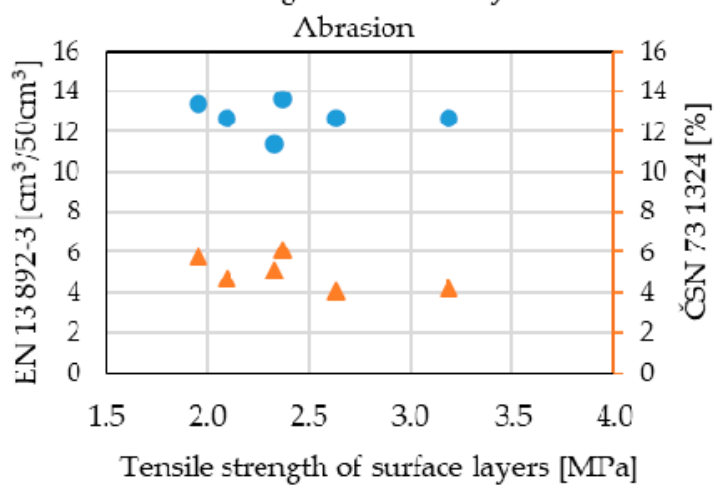

(c) •EN 13 892-3 $\Delta$ CSN 731327

Figure 4. Mechanical parameters of produced concretes and their resistance to mechanical abrasion: (a) Compressive strength; (b) Tensile strength; (c) Tensile strength of surface layers. 


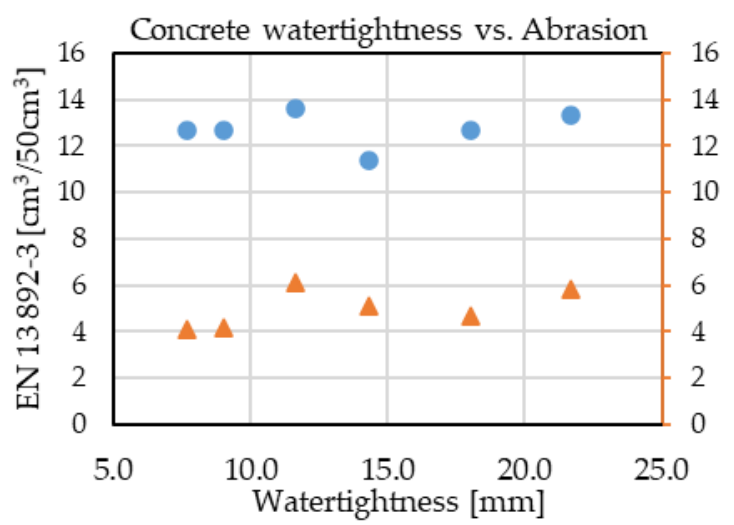

(a) • EN 13 892-3 $\Delta$ CSN 731327

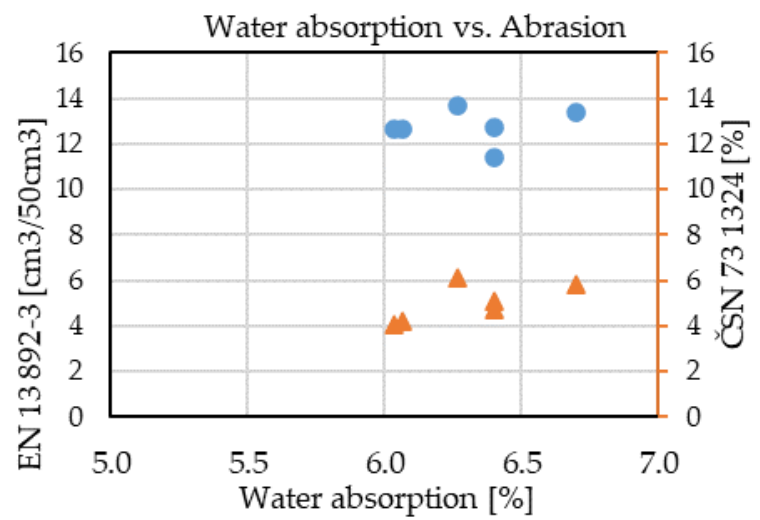

(b) •EN 13 892-3 $\Delta$ CSN 731327

Figure 5. Durability parameters of produced concretes and their resistance to mechanical abrasion:

(a) Concrete watertightness; (b) Water absorption.

Within the performed graphical evaluation of the determined parameters of the produced concrete after 28 and 90 days, certain linear dependences were sought. In order to more accurately determine the possible dependences of individual mechanical and durability parameters and the resistance of composites to mechanical abrasion, the Pearson's correlation coefficient was calculated. Pearson's correlation coefficient is a statistical indicator of the strength of a linear dependence between two quantities. It takes values from -1.0 to 1.0 , and the closer the value is to 1 or -1 , the stronger the linear correlation between the tested quantities is. Positive values indicate a positive linear correlation and negative ones indicate a negative linear correlation. A value of 0 indicates that there is no linear correlation between the examined variables $[35,36]$. This coefficient was always determined for the given parameter after 28 or 90 days. The results are provided in Table 6.

Table 6. Pearson's correlation coefficient results.

\begin{tabular}{clcc}
\hline Parameter/Test & & CSN 73 1324 & EN 13 892-3 \\
\hline \multirow{2}{*}{ Compressive strength } & 28 days & -0.26 & -0.43 \\
& 90 days & 0.02 & -0.13 \\
Flexural strength & 28 days & -0.45 & -0.60 \\
& 90 days & -0.98 & -0.94 \\
Tensile strength of surface layers & 28 days & -0.18 & -0.35 \\
& 90 days & -0.77 & -0.86 \\
Concrete watertightness & 28 days & 0.04 & 0.21 \\
& $\mathbf{9 0}$ days & 1.00 & 1.00 \\
Water absorption & 28 days & -0.02 & 0.16 \\
& $\mathbf{9 0}$ days & 1.00 & 0.97 \\
Crush resistance-LA & 28 days & 0.68 & 0.80 \\
& 90 days & 0.93 & 0.87 \\
\hline
\end{tabular}

Using Pearson's correlation coefficient, it was possible to prove that the results of the resistance of concrete to mechanical abrasion did not depend on the compressive strength of concrete, neither after 28 days nor after 90 days. From the point of view of other mechanical parameters of produced concretes, a significant dependence from the point of view of their influence on abrasion resistance of composite can be seen in flexural strength and tensile strength of concrete surface layers after 90 days of composite maturing. A very significant dependence of the resistance of concrete to mechanical abrasion can be seen in the watertightness and water absorption of concrete after 90 days of maturing and in the resistance of aggregate grains to crushing caused by the Los Angeles method. These results give a very good picture of the obvious dependence of used aggregates into concrete composite on its resulting resistance to mechanical abrasion. 
From the point of view of determining the abrasiveness of concrete in accordance with EN 13 892-3, the achievement of practically comparable values after 90 days of maturing appears to be very positive. From these results, it can be concluded that the quality of the aggregate plays the most important role in terms of resistance of concrete to abrasion in the early stages of maturing and with a longer period of time, its function mainly becomes dependent on the properties of the cement matrix itself.

Summary:

- The mix designs with crushed aggregate show higher values of tensile strength

- No relationship was found between the abrasion resistance of the composite and its compressive strength

- Significant dependences of the abrasion resistance of the composite and its tensile strengths were observed after 90 days of maturation

- Significant dependence between the resistance of concrete to mechanical abrasion and its watertightness and absorbency were observed after 90 days of curing

- After a longer time period of maturation of the composite (90 days), the differences in the influence of individual types of aggregates were reduced—quality crushed $x$ fluvial sedimentary

A significant influence of aggregate was found at the beginning of composite maturation In a longer time period, cement stone took over the main function.

\section{Influence of Mineral Additives on the Resistance of Concrete to Mechanical Abrasion}

This part of the experiment aimed to clarify the effect of commonly used mineral additives on the resistance of concrete to mechanical abrasion. In accordance with the EN $206+$ A1 standard, we generally distinguished between two types of additives: an inert additive of type I and an additive with pozzolanic or latent hydraulic capability of type II. For many years, the production of concrete with special utility properties within the framework of modern concrete technology was almost impossible without the use of both types of additives. Abrasion resistance could undoubtedly be included among these properties. However, there were noticeable differences between the individual additives not only in their effect on fresh and hardened concrete, but also in their purchase prices. The question of the experiment was to determine whether the frequent increase in price when using some types of additives affected their otherwise positive effect on the abrasion resistance of concrete. These highly active additives, such as microsilica, are expected to have a positive impact on the microstructure of the composite. Its strong pozzolanic reaction gives rise to neoplasms similar to Portland cement hydration products, generally CSH and CAH gels, which thicken the microstructure of the composite and thus have a positive effect on its mechanical and durability parameters [37,38]. Other types of additives are then mainly often used for abrasion-resistant concretes in terms of positively influencing the development of heat of hydration, which results in the elimination of negative volume changes leading to the formation of microcracks $[39,40]$. These additives include, for example, ground limestones and high-temperature fly ashes.

The following mineral additives were selected for the experiment:

- Very finely ground limestone, locality: Zblovice-Czech Republic

- Very finely ground granulated blast furnace slag, locality: Detmarovice—Czech Republic

- Coal high-temperature fly ash, locality: Detmarovice-Czech Republic

- Microsilica, locality: Istebne-Slovak Republic.

\subsection{Experiment of Influence of Mineral Additives on the Resistance of Concrete to Mechanical Abrasion}

All mineral additives used were first analyzed to demonstrate their basic mechanical and physical parameters, such as their specific surface area, specific weight and ignition loss, and then were subjected to a quantitative analysis of the proportion of basic oxides by using XRF (X-ray fluorescence). All of 
these parameters are included in Tables 7 and 8 . The mineral additives used met the relevant normative values for use as additives in concrete in accordance with EN $206+$ A1.

Table 7. Quantitative XRF (X-ray fluorescence) analysis of represented oxides.

\begin{tabular}{ccccc}
\hline Parameter/Designation & Limestone & Slag & Fly Ash & Microsilica \\
\hline $\mathrm{SiO}_{2}(\%)$ & 0.45 & 32.22 & 58.10 & 91.10 \\
$\mathrm{Al}_{2} \mathrm{O}_{3}(\%)$ & 0.32 & 8.07 & 22.20 & 0.30 \\
$\mathrm{Fe}_{2} \mathrm{O}_{3}(\%)$ & 0.13 & 1.16 & 7.46 & 0.67 \\
$\mathrm{CaO}(\%)$ & 96.5 & 48.02 & 3.80 & 0.19 \\
$\mathrm{MgO}(\%)$ & 0.79 & 6.71 & 2.56 & 1.24 \\
$\mathrm{Na} 2 \mathrm{O}(\%)$ & 0.01 & 0.37 & 0.50 & 0.50 \\
$\mathrm{~K}_{2} \mathrm{O}(\%)$ & 0.01 & 0.79 & 2.72 & 1.50 \\
$\mathrm{SO}_{3}(\%)$ & 0.04 & 0.00 & 0.20 & 0.67 \\
\hline
\end{tabular}

Table 8. Properties of the analyzed mineral additives.

\begin{tabular}{|c|c|c|c|c|c|}
\hline \multicolumn{2}{|c|}{ Parameter/Designation } & Limestone & Slag & Fly Ash & Microsilica \\
\hline \multicolumn{2}{|c|}{ Specific weight $\left(\mathrm{kg} / \mathrm{m}^{3}\right)$} & 2720 & 2965 & 2334 & 2320 \\
\hline \multicolumn{2}{|c|}{$\begin{array}{l}\text { Grinding fineness-specific } \\
\text { surface-Blaine }\left(\mathrm{m}^{2} / \mathrm{kg}\right)\end{array}$} & 4320 & 3530 & 3180 & 21,830 * \\
\hline \multicolumn{2}{|c|}{ Ignition loss (\%) } & 46.8 & 0.7 & 2.8 & 2.1 \\
\hline \multirow{3}{*}{ Efficiency index (\%) } & 7 days & 81 & 77 & 79 & 83 \\
\hline & 28 days & 83 & 100 & 84 & 116 \\
\hline & 90 days & 86 & 108 & 92 & 126 \\
\hline
\end{tabular}

* Note: Specific surface-BET $\left(\mathrm{m}^{2} / \mathrm{kg}\right)$

The determined efficiency index was obtained by replacing $25 \%$ of the weight of Portland cement with the given additive, except for microsilica, where the replacement was $10 \%$. These results show a significant activity of microsilica, and blast furnace slag in particular. The results of the activity of very finely ground limestone, which is considered as an inert additive in accordance with current legislation, indicate agreement with some research that attributes hidden activity to very finely ground limestone in terms of crystallization seeds formation during cement hydration [41,42]. Using these results, several concrete formulas of the strength class C 35/45 were designed for the next experiment, maintaining the same grading curve, the same consistency and the same compressive strength after 28 days. Thanks to this approach, it is possible to only assess the effect of a given mineral additive on the subsequent resistance of concrete to mechanical abrasion while eliminating other effects in the form of aggregates, mechanical properties or processability of the mixture.

For a connection with the previous experiment, the same cement CEM I $42.5 \mathrm{R}$ from the production of the Mokra (HeidelbergCement-Germany) cement plant from Czech Republic, the same superplasticizers MC Powerflow 2695 produced by the company MC Bauchemie and the same aggregate psammite type were used. The same grading curve shown in Figure 2, as well as the same test procedures were also employed. The dosage of binders was designed with regard to the standard dosing of individual types of admixtures and the maintenance of approximately the same compressive strength of all mix designs after 28 days.

Verification of Properties of Designed Concretes with Mineral Additives

For fresh concretes, as in the previous case, the density in the fresh state in accordance with EN 12350-6 [26] and the degree of consistency by the cone slump method in accordance with EN 12350-2 [25] within 5 min of production were determined. The results of these tests are given in Table 10. Table 9 accurately shows the designed formulas of the analyzed concretes using mineral additives.

All produced concretes achieved the same degree of consistency in the cone slump test. In order to achieve this parameter, the dose of water and superplasticizer was slightly adjusted for each formula, as can be seen from Table 9 . 
The results of tests on hardened concrete are shown in Tables 11 and 12, and the proposed test procedures fully correspond to the procedures performed in the first part of the experiment to determine the effect of aggregate on the resistance of concrete to mechanical abrasion.

Table 9. Composition of concrete mixtures with mineral additives.

\begin{tabular}{cccccc}
\hline Raw Material/Designation & PSM & PSM-L & PSM-S & PSM-F & PSM-M \\
\hline CEM I 42.5 R (kg) & 335 & 320 & 290 & 305 & 305 \\
Limestone (kg) & - & 70 & - & - & - \\
Slag (kg) & - & - & 90 & - & - \\
Fly ash (kg) & - & - & - & 80 & - \\
Microsilica (kg) & - & - & - & - & 30 \\
0-4 Psammite (\%) & & & 45.9 & & \\
4-8 Psammite (\%) & & & 13.4 & & \\
8-16 Psammite (\%) & 165 & 165 & 170 & 165 & 170 \\
Water (kg) & 0.85 & 0.82 & 0.82 & 0.81 & 0.99 \\
Superplasticizer $(\%)$ of $\mathrm{m}_{\mathrm{b}}{ }^{*}$ & $*$ Note: $\mathrm{m}_{\mathrm{b}}$-amount of all binders. &
\end{tabular}

Table 10. Properties of fresh concrete (FC).

\begin{tabular}{cccccc}
\hline Parameter/Designation & PSM & PSM-L & PSM-S & PSM-F & PSM-M \\
\hline Density $\left(\mathrm{kg} / \mathrm{m}^{3}\right)$ & 2330 & 2360 & 2360 & 2330 & 2330 \\
Slump consistency $(\mathrm{mm})$ & 170 & 170 & 170 & 170 & 160 \\
\hline
\end{tabular}

\subsection{Discussion of Results}

Thanks to the analysis of the efficiency index of individual additives before the production of concrete mixtures, it was possible to consider these numbers when creating concrete formulas and thus design mixtures with a corresponding value of compressive strength after 28 days of standard maturation. The results of compressive strength show a significant activity of some additives, and this activity was manifested even after 28 days of normal maturation. The positive benefits of the addition of all types of analyzed mineral additives include their positive impact on the flexural strength of concrete, and especially on its tensile strength of surface layers. The second mentioned parameter for all types of mineral additives was improved by at least $14 \%$ after 28 days and by at least $10 \%$ after 90 days. In both cases, this parameter was high temperature fly ash. In the case of a maximum increase of this parameter, the equivalent increase was $41 \%$ after 28 days and $51 \%$ after 90 days. These numbers are related to the improvement of the microstructure of the composite and especially to the transit zone between the aggregate grains and the cement stone. In this case, the use of very finely ground limestone seems to be very beneficial, although it is not an active ingredient according to the valid normative legislation.

A positive effect on the addition of all types of mineral additives can also be seen in the value of the watertightness of concrete. This parameter, together with the tensile strength of the concrete surface layers, could have a favorable effect on the resistance of the concrete to mechanical abrasion.

From the point of view of determining the abrasion of concrete, a very significant difference between the results after 28 and 90 days was evident for all of the types of mineral additives used, i.e., including very finely ground limestone, which is considered to be inert. Although all produced concretes after 28 days of standard maturation show completely comparable compressive strength results and higher values of flexural strength and tensile strength of surface layers of concrete compared to concrete without additives, the results of mechanical abrasion resistance determined by Böhm's device show a different trend. This outcome could be related to the total amount of binder component in relation to the amount of aggregate used for the production of $1 \mathrm{~m}^{3}$ of concrete. Due to the addition of all types of additives except for microsilica, which shows comparable results with the formula completely 
without additive, the binder component was increased for all formulas in order to achieve the same compressive strength after 28 days. Thanks to this, the total aggregate dose had to be corrected to keep $1 \mathrm{~m}^{3}$ of concrete according to the equation of absolute volumes. This outcome is with the results of a previous experiment, where it was shown that aggregate plays an important role in terms of abrasion resistance in the early stages of composite maturation. The results are underlined by the following graphic evaluation, which compares the abrasiveness of concrete after 28 days and the amount of cement paste in the formula, i.e., the dose of binders, water and superplasticizer. After 90 days of maturation, when the microstructure of the concrete was already significantly improved by the ongoing reactions of mineral additives, the overall abrasion resistance of the concrete increased significantly, regardless of the type of aggregate used. This result is essential for the correct design of a concrete mixture with high resistance to mechanical abrasion, if we know the time when the whole structure will be put into operation and be exposed to abrasive stress. The unambiguous impact of the use of mineral additives on the resistance of concrete to mechanical abrasion at the time of maturing was proven. Graphical results are shown in Figure 6.

Table 11. Mechanical and physical parameters of tested concretes with mineral additives.

\begin{tabular}{|c|c|c|c|c|c|c|}
\hline \multicolumn{2}{|c|}{ Parameter/Designation } & \multirow{2}{*}{$\begin{array}{l}\text { PSM } \\
2320\end{array}$} & \multirow{2}{*}{$\begin{array}{c}\text { PSM-L } \\
2350\end{array}$} & \multirow{2}{*}{$\begin{array}{c}\text { PSM-S } \\
2360\end{array}$} & \multirow{2}{*}{$\begin{array}{l}\text { PSM-F } \\
2340\end{array}$} & \multirow{2}{*}{$\frac{\text { PSM-M }}{2330}$} \\
\hline \multirow{9}{*}{ Density $\left(\mathrm{kg} / \mathrm{m}^{3}\right)$} & $\begin{array}{c}7 \\
\text { days }\end{array}$ & & & & & \\
\hline & SD & 5 & 8 & 0 & 5 & 0 \\
\hline & $\mathrm{CV}$ & 0.2 & 0.4 & 0.0 & 0.2 & 0.0 \\
\hline & $\begin{array}{c}28 \\
\text { days }\end{array}$ & 2340 & 2360 & 2350 & 2330 & 2330 \\
\hline & SD & 5 & 0 & 45 & 8 & 5 \\
\hline & $\mathrm{CV}$ & 0.2 & 0.0 & 0.2 & 0.4 & 0.2 \\
\hline & $\begin{array}{c}90 \\
\text { days }\end{array}$ & 2340 & 2360 & 2360 & 2330 & 2330 \\
\hline & SD & 5 & 0 & 8 & 9 & 0 \\
\hline & CV & 0.2 & 0.0 & 0.4 & 0.4 & 0.0 \\
\hline \multirow{9}{*}{$\begin{array}{l}\text { Compressive } \\
\text { strength (MPa) }\end{array}$} & $\begin{array}{c}7 \\
\text { days }\end{array}$ & 21.8 & 24.7 & 26.9 & 24.5 & 34.6 \\
\hline & SD & 0.5 & 0.4 & 0.3 & 0.3 & 0.5 \\
\hline & $\mathrm{CV}$ & 2.3 & 1.4 & 1.2 & 1.3 & 1.4 \\
\hline & $\begin{array}{c}28 \\
\text { days }\end{array}$ & 51.2 & 49.3 & 55.3 & 51.5 & 48.2 \\
\hline & SD & 0.2 & 0.5 & 0.1 & 0.6 & 0.8 \\
\hline & $\mathrm{CV}$ & 0.3 & 0.9 & 0.2 & 1.2 & 1.7 \\
\hline & $\begin{array}{c}90 \\
\text { days }\end{array}$ & 60.0 & 56.3 & 60.5 & 61.2 & 60.1 \\
\hline & SD & 0.5 & 0.3 & 0.3 & 0.1 & 0.4 \\
\hline & $\mathrm{CV}$ & 0.8 & 0.6 & 0.6 & 0.2 & 0.6 \\
\hline \multirow{6}{*}{$\begin{array}{l}\text { Flexural strength } \\
\text { (MPa) }\end{array}$} & $\begin{array}{c}28 \\
\text { days }\end{array}$ & 5.0 & 5.2 & 5.0 & 5.4 & 5.2 \\
\hline & SD & 0.1 & 0.2 & 0.1 & 0.1 & 0.1 \\
\hline & $\mathrm{CV}$ & 2.8 & 3.3 & 2.5 & 1.5 & 3.1 \\
\hline & $\begin{array}{c}90 \\
\text { days }\end{array}$ & 5.5 & 6.1 & 6.3 & 6.2 & 5.9 \\
\hline & SD & 0.1 & 0.2 & 0.2 & 0.0 & 0.2 \\
\hline & CV & 2.2 & 4.1 & 3.4 & 0.8 & 3.7 \\
\hline \multirow{6}{*}{$\begin{array}{l}\text { Tensile strength of } \\
\text { surface layers } \\
\text { (MPa) }\end{array}$} & $\begin{array}{c}28 \\
\text { days }\end{array}$ & 1.95 & 2.75 & 2.29 & 2.22 & 2.71 \\
\hline & SD & 0.07 & 0.04 & 0.03 & 0.03 & 0.05 \\
\hline & CV & 3.72 & 1.47 & 1.29 & 1.13 & 1.98 \\
\hline & $\begin{array}{c}90 \\
\text { days }\end{array}$ & 2.09 & 2.83 & 2.44 & 2.30 & 3.15 \\
\hline & SD & 0.03 & 0.09 & 0.05 & 0.01 & 0.09 \\
\hline & $\mathrm{CV}$ & 1.35 & 3.19 & 2.04 & 0.41 & 2.99 \\
\hline
\end{tabular}

Note: SD—Standard deviation, CV—coefficient of variation (\%). 
Table 12. Results of durability parameters of tested concretes with mineral additives.

\begin{tabular}{|c|c|c|c|c|c|c|}
\hline \multicolumn{2}{|c|}{ Parameter/Designation } & \multirow{2}{*}{$\begin{array}{c}\text { PSM } \\
22\end{array}$} & \multirow{2}{*}{$\begin{array}{c}\text { PSM-L } \\
18\end{array}$} & \multirow{2}{*}{$\begin{array}{c}\text { PSM-S } \\
12\end{array}$} & \multirow{2}{*}{$\begin{array}{c}\text { PSM-F } \\
15\end{array}$} & \multirow{2}{*}{$\begin{array}{c}\text { PSM-M } \\
23\end{array}$} \\
\hline \multirow{6}{*}{$\begin{array}{c}\text { Concrete } \\
\text { watertightness } \\
(\mathrm{mm})\end{array}$} & 28 days & & & & & \\
\hline & SD & 2 & 2 & 2 & 0 & 2 \\
\hline & $\mathrm{CV}$ & 11.5 & 9.3 & 14.6 & 3.1 & 8.8 \\
\hline & 90 days & 18 & 14 & 8 & 12 & 14 \\
\hline & SD & 2 & 2 & 1 & 2 & 2 \\
\hline & $\mathrm{CV}$ & 9.1 & 15.0 & 10.2 & 13.6 & 17.5 \\
\hline \multirow{6}{*}{$\begin{array}{c}\text { Water absorption } \\
(\%)\end{array}$} & 28 days & 6.7 & 6.6 & 6.2 & 6.4 & 7.0 \\
\hline & SD & 0.1 & 0.1 & 0.1 & 0.0 & 0.1 \\
\hline & $\mathrm{CV}$ & 2.1 & 1.2 & 1.3 & 0.7 & 1.8 \\
\hline & 90 days & 6.4 & 6.4 & 6.0 & 6.3 & 6.8 \\
\hline & SD & 0.1 & 0.1 & 0.1 & 0.2 & 0.1 \\
\hline & $\mathrm{CV}$ & 2.2 & 1.4 & 2.1 & 2.5 & 1.8 \\
\hline \multirow{6}{*}{$\begin{array}{l}\text { Determination of } \\
\text { abrasion according } \\
\text { to EN } 13892-3 \\
\left(\mathrm{~cm}^{3} / 50 \mathrm{~cm}^{3}\right)\end{array}$} & 28 days & 13.35 & 14.10 & 14.45 & 15.00 & 13.10 \\
\hline & SD & 0.13 & 0.17 & 0.06 & 0.10 & 0.09 \\
\hline & CV & 0.61 & 1.21 & 0.43 & 0.68 & 0.65 \\
\hline & 90 days & 12.70 & 12.35 & 12.20 & 12.45 & 11.65 \\
\hline & SD & 0.13 & 0.11 & 0.08 & 0.23 & 0.06 \\
\hline & $\mathrm{CV}$ & 0.98 & 0.87 & 0.70 & 1.81 & 0.54 \\
\hline \multirow{6}{*}{$\begin{array}{l}\text { Determination of } \\
\text { concrete abrasion } \\
\text { according to CSN } \\
731324(\%)\end{array}$} & 28 days & 5.80 & 6.10 & 6.30 & 6.50 & 5.90 \\
\hline & SD & 0.09 & 0.09 & 0.19 & 0.22 & 0.09 \\
\hline & $\mathrm{CV}$ & 1.47 & 1.55 & 2.99 & 3.32 & 1.60 \\
\hline & 90 days & 4.70 & 4.50 & 4.40 & 4.30 & 4.70 \\
\hline & SD & 0.13 & 0.14 & 0.14 & 0.05 & 0.13 \\
\hline & $\mathrm{CV}$ & 2.65 & 3.14 & 3.21 & 1.10 & 2.65 \\
\hline
\end{tabular}

Note: SD—Standard deviation, CV—coefficient of variation (\%).

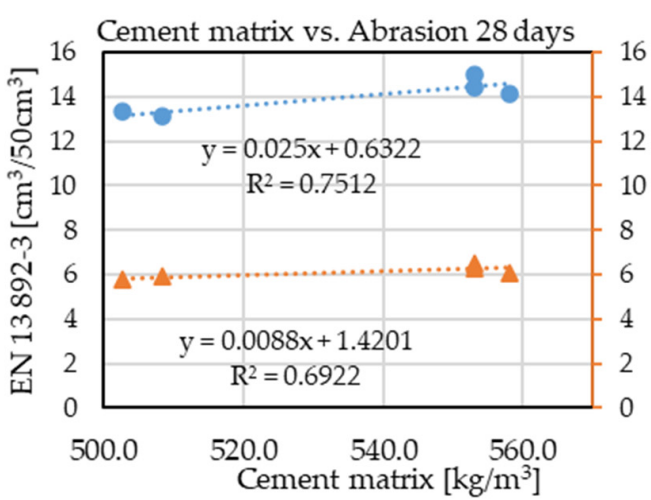

(a) •EN 13 892-3 $\Delta$ CSN 731327

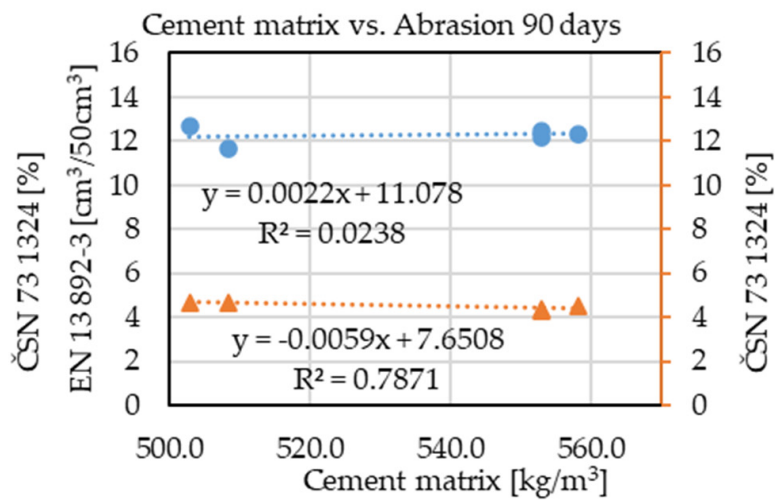

(b) •EN 13 892-3 $\Delta$ CSN 731327

Figure 6. Cement paste amount of produced concretes and their resistance to mechanical abrasion:

(a) 28 days; (b) 90 days.

From the displayed graphic dependence, the conclusion about the negative impact of the amount of cement paste in concrete at the expense of aggregate at an early stage of maturation on the abrasion resistance of the composite can be confirmed. This dependence is practically linear after 28 days and its dependence on the time of maturation decreases, as can be seen in the graph with the results after 90 days of maturation. The assessment of individual monitored parameters concerning the abrasion resistance of concrete is shown in Figures 7 and 8. 


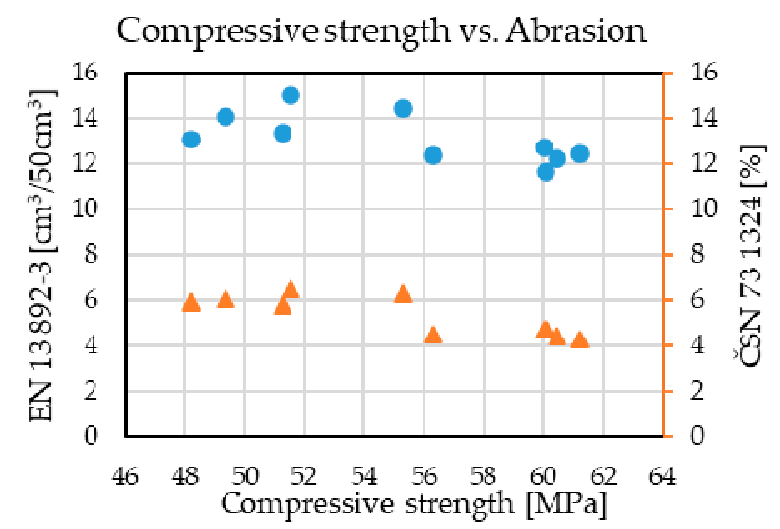

(a) • EN 13 892-3 $\Delta$ CSN 731327

Tensile strength vs. Abrasion

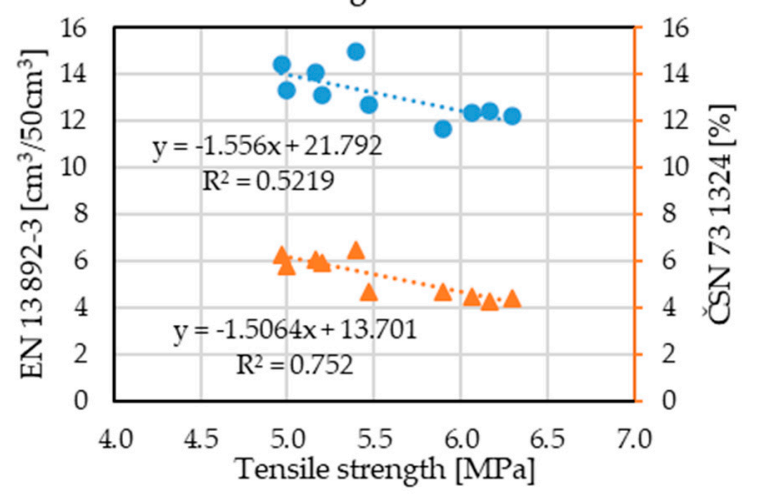

(b) • EN 13 892-3 $\Delta$ CSN 731327

Tensile strength of surfacelayers vs.

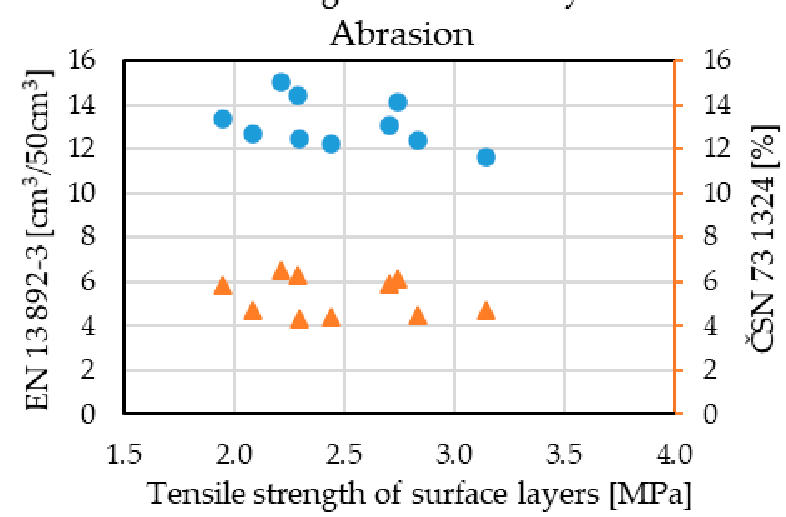

(c) •EN 13 892-3 $\Delta$ CSN 731327

Figure 7. Mechanical parameters of produced concretes and their resistance to mechanical abrasion: (a) Compressive strength; (b) Tensile strength; (c) Tensile strength of surface layers.

In the graphical evaluation of the produced concretes, the summary results after 28 and 90 days can be seen again. In order to determine the possible dependences of individual mechanical and durability parameters and the resistance of composites to mechanical abrasion in more detail, the Pearson's correlation coefficient was calculated. The results are contained in Table 13. 
Concrete watertightness vs. Abrasion

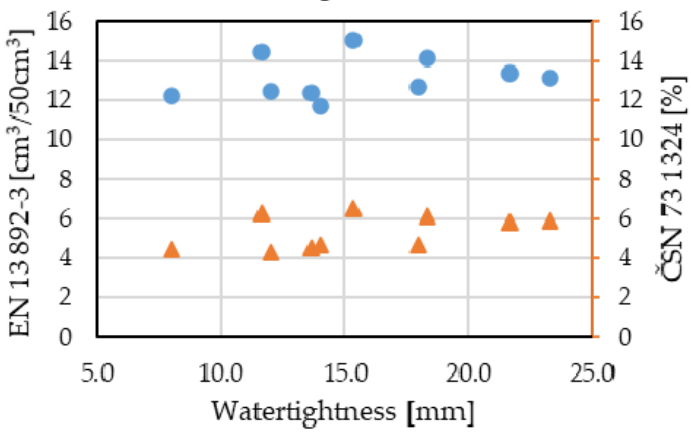

(a) •EN 13 892-3 $\Delta$ CSN 731327

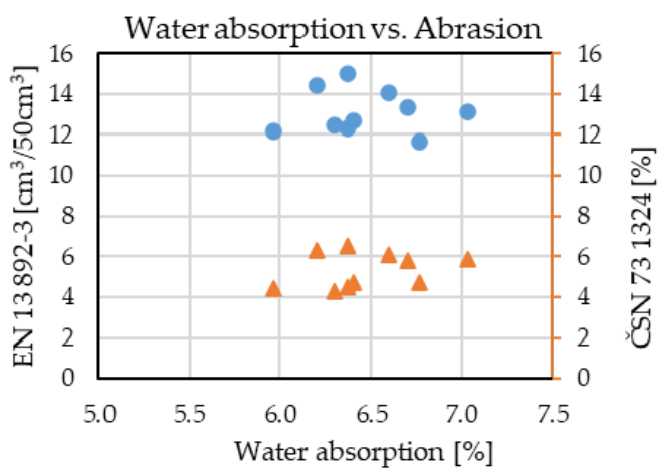

(b) • EN 13 892-3 $\Delta$ CSN 731327

Figure 8. Durability parameters of produced concretes and their resistance to mechanical abrasion: (a) Concrete watertightness; (b) Water absorption.

Table 13. Results of durability parameters of tested concretes with mineral additives.

\begin{tabular}{clcc}
\hline \multicolumn{2}{c}{ Parameter/Test } & CSN 73 1324 & EN 13 892-3 \\
\hline \multirow{2}{*}{ Compressive strength } & 28 days & 0.50 & 0.55 \\
& 90 days & -0.17 & -0.06 \\
Flexural strength & 28 days & 0.54 & 0.46 \\
Tensile strength of & $\mathbf{9 0}$ days & -0.84 & -0.26 \\
surface layers & $\mathbf{2 8}$ days & -0.05 & -0.17 \\
Concrete watertightness & $\mathbf{9 0}$ days & 0.29 & -0.88 \\
& 28 days & -0.87 & -0.88 \\
Water absorption & $\mathbf{9 0}$ days & 0.72 & 0.31 \\
& 28 days & -0.77 & -0.85 \\
& 90 days & 0.69 & -0.53 \\
\hline
\end{tabular}

Using Pearson's correlation coefficient, it was possible to prove that there were very significant differences in almost all observed dependences between selected mechanical and durability parameters and the resistance of the composite to mechanical abrasion after 28 and 90 days of standard maturation. The most important factors in this case also appear to be the watertightness and water absorption of the concrete, but only after a longer period of maturation, for the experiment that involved 90 days of standard maturation. Certain dependencies can again be found between the flexural strength, the tensile strength of the surface layers and the abrasion resistance. These results also seem to have a significant dependence on the microstructure of the composite, which becomes more compact over a longer period of time, especially when active ingredients are used.

The results show an unambiguous impact of mineral additives on the resistance of concrete to mechanical abrasion over time and point to the possibility of using inert additives as a very effective tool to increase the resistance of cement composite to mechanical abrasion if a maturation period longer than 28 days is observed before loading the structure.

In summary, we:

- confirmed the existence of a positive influence of mineral admixtures on tensile parameters of composite and its watertightness

- demonstrated a positive effect of inert admixtures - these led to a very finely ground limestone

- noted significant impacts of the use of mineral admixtures on the resistance of the composite to mechanical abrasion over time:

In the early-stage, we noted the development of worse resistance (increased dose of binder component at the expense of aggregate-the main carrier of resistance in the early stage) 
$0 \quad$ In the longer term, they increased the resistance of the composite to mechanical abrasion-this was the course for delayed hydration processes.

\section{Influence of the Addition of Dispersed Reinforcement on the Resistance of Concrete to Mechanical Abrasion}

In this last part of the experiment, the impact of the addition of dispersed reinforcement on the resistance of the concrete to mechanical abrasion was verified. The use of dispersed reinforcement has its justification, especially where it is necessary to increase the resistance of the concrete to mechanical shocks, increase its resistance to the effects of high temperatures or reduce the risk of its volume changes. However, some authors also consider the addition of dispersed reinforcement to be a suitable tool for increasing the abrasion resistance of the composite [43-45]. The theory on which these authors rely is the fact that dispersed microfibers can have a positive effect on the elimination of volume changes of the composite, which are undesirable from the point of view of the subsequent abrasion resistance of the composite. However, they also rely on the theory that the dispersed reinforcement is a blocker of direct exposure of the microstructure and interconnects and holds the individual parts of the composite together, even if it is already disrupted [46,47].This positive effect has already been demonstrated in several studies in the case of the addition of carbon nanotubes, which, as has been shown, not only act as dispersed forms of nano-reinforcement, but also contribute positively to the thickening of the microstructure of the composite [48]. Although the use of nanotubes appears to be beneficial according to some scientific studies, their cost for use in practice is not at all favorable. For this reason, polymeric, steel, polypropylene, cellulosic or other types of fibers are preferred. Other research groups point to the fact that if the fiber is exposed, it is then further stressed by abrasion until it is torn out of the composite and thus a defect in the surface of the structure is formed. This site is then less resistant to abrasion than the compact composite, and thus the degradation of the composite progresses [49]. However, many studies state that this mainly affects solid and inflexible steel fibers or other fibers with significant stiffness, such as glass fibers. [50] Following the approach of previous studies discussed in this article, only flexible polymeric and basalt fibers were selected for this experiment [46-49].

\subsection{Experiment of Influence of the Addition of Dispersed Reinforcement on the Resistance of Concrete to Mechanical Abrasion}

From each type of fiber, one representative was selected with respect to their approximately comparable dimensions. In both cases, they were monofilament fibers. The fibers are shown in Figure 9.

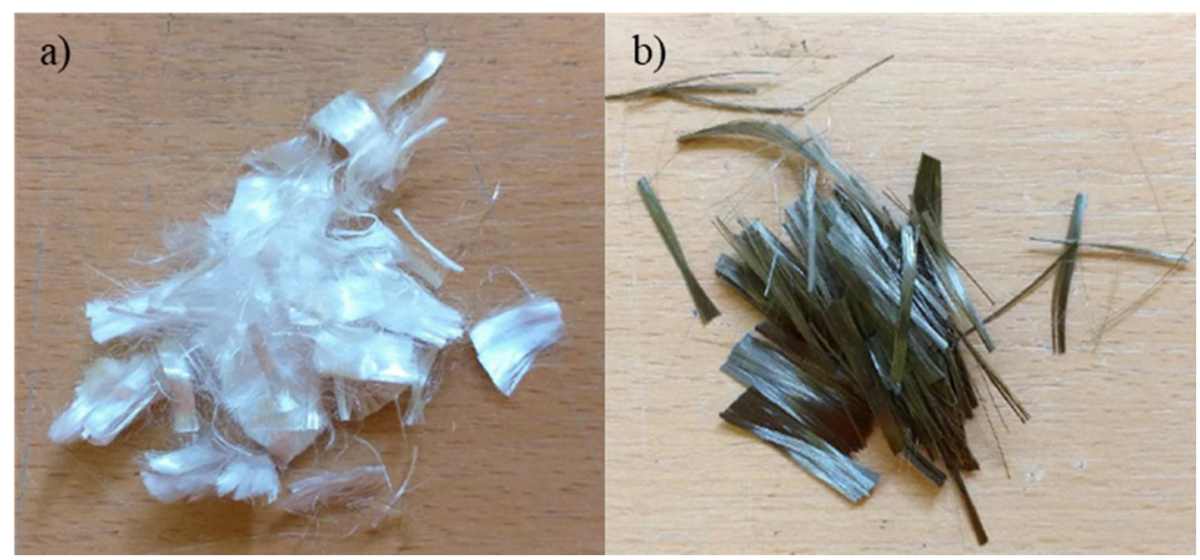

Figure 9. Photographs of fibers used: (a) PM fibers, (b) BF fibers.

The following fibers were selected for the experiment:

- $\quad$ Polypropylene fibers PM 12/18

- Basalt fibers BF 13-24p. 
The properties of the used micro fibers are discussed in Table 14 and their dosage was chosen taking the recommendations of the manufacturer and supplier into account.

Table 14. Properties of the micro fibers used.

\begin{tabular}{ccc}
\hline Parameter/Designation & PM & BF \\
\hline Basic fiber diameter $(\mu \mathrm{m})$ & 18 & 13 \\
Fiber length $(\mathrm{mm})$ & 12 & 24 \\
Tensile strength $(\mathrm{MPa})$ & 300 & 1920 \\
Tensile modulus of elasticity $(\mathrm{MPa})$ & $1.3-1.8$ & 100,000 \\
\hline
\end{tabular}

Significant differences between the fibers resulted from the properties of the fibers used, especially in the mechanical parameters. No positive contribution to the mechanical parameters of the composite was expected from the use of this dispersed reinforcement, and in order to maintain the format from the previous parts of the experiment, concrete of strength class C 35/45 was designed to have the same grading curve, the same consistency and the same compressive strength after 28 days. The addition of very finely ground limestone was chosen for this part of the experiment.

For the connection with the previous experiment, the same cement CEM I $42.5 \mathrm{R}$ from the production of the Mokra (HeidelbergCement-Germany) cement plant from Czech Republic, the same superplasticizer MC Powerflow 2695 produced by the company MC Bauchemie and the same aggregate psammite type were used. Also, the same grading curve according to Figure 2 and the same test procedures were maintained.

When mixing the fresh mixture, it first used mixed dry aggregates and the fibers for about $2 \mathrm{~min}$. After mixing these components, cement was added to the mixture together with very finely ground limestone and both mixing water and superplasticizer.

Table 15 accurately shows the designed formulas of the analyzed concretes using dispersed fibers.

Table 15. Composition of concrete mixtures with dispersed fibers.

\begin{tabular}{cccc}
\hline Raw Material/Designation & PSM-L & PSM-PM & PSM-BF \\
\hline CEM I 42.5 R (kg) & 320 & 320 & 320 \\
Limestone Zblovice (kg) & 70 & 70 & 70 \\
PP Fibres PM (kg) & - & 1.0 & - \\
Basalt fibers BF (kg) & - & - & 2.0 \\
0-4 Psammite (\%) & & 45.9 & \\
4-8 Psammite (\%) & & 13.4 & \\
8-16 Psammite (\%) & 165 & 185 & 180 \\
Water (kg) & 0.84 & 0.95 & 0.91 \\
Superplasticizer (\%) of $\mathrm{m}_{\mathrm{b}}{ }^{*}$ & * Note: $\mathrm{m}_{\mathrm{b}}$-amount of all binders.
\end{tabular}

\section{Verification of Properties of Designed Fiber Concretes}

For fresh concretes, as in the previous cases, the density in the fresh state in accordance with EN 12350-6 [26] and the degree of consistency by the slump cone method in accordance with EN 12350-2 [25] within $5 \mathrm{~min}$ from production were determined. The results of these tests are given in Table 16.

Table 16. Properties of fresh concrete.

\begin{tabular}{cccc}
\hline Parameter/Designation & PSM-L & PSM-PM & PSM-BF \\
\hline Density $\left(\mathrm{kg} / \mathrm{m}^{3}\right)$ & 2340 & 2330 & 2350 \\
Consistency by slump $(\mathrm{mm})$ & 190 & 190 & 200 \\
\hline
\end{tabular}


The results show that it was possible to achieve a consistency using a slump cone of about $190 \mathrm{~mm}$ using the recommended doses of polypropylene and basalt fibers, although an increase in the dose of mixing water and superplasticizer had to be made. This fact is due to the overall increase in the specific surface area of the composite components thanks to the addition of microfibers. The necessary increase of the water-cement ratio served to wet the surface of the applied fibers.

The results of tests on hardened concrete are shown in Tables 17 and 18 and the designed test procedures fully correspond to the procedures performed in the previous parts of the experiment.

Table 17. Mechanical and physical parameters of the tested fiber concretes.

\begin{tabular}{|c|c|c|c|c|c|c|c|c|c|c|}
\hline \multirow{2}{*}{\multicolumn{2}{|c|}{ Parameter/Designation }} & \multicolumn{3}{|c|}{ PSM-L } & \multicolumn{3}{|c|}{ PSM-PM } & \multicolumn{3}{|c|}{ PSM-BF } \\
\hline & & \multicolumn{2}{|c|}{ Mean SD } & \multirow{2}{*}{$\begin{array}{l}\mathbf{C V} \\
0.3\end{array}$} & \multicolumn{2}{|c|}{ Mean SD } & \multirow{2}{*}{$\begin{array}{l}\text { CV } \\
0.2\end{array}$} & \multicolumn{2}{|c|}{ Mean SD } & \multirow{2}{*}{$\begin{array}{l}\text { CV } \\
0.2\end{array}$} \\
\hline \multirow{3}{*}{ Density $\left(\mathrm{kg} / \mathrm{m}^{3}\right)$} & 7 days & 2370 & 8 & & 2350 & 5 & & 2350 & 5 & \\
\hline & 28 days & 2370 & 0 & 0.0 & 2360 & 8 & 0.4 & 2350 & 5 & 0.2 \\
\hline & 90 days & 2380 & 5 & 0.2 & 2370 & 5 & 0.2 & 2360 & 5 & 0.2 \\
\hline \multirow{3}{*}{$\begin{array}{l}\text { Compressive } \\
\text { strength (MPa) }\end{array}$} & 7 days & 31.3 & 0.2 & 0.7 & 30.9 & 0.4 & 1.2 & 33.6 & 0.3 & 0.8 \\
\hline & 28 days & 52.3 & 0.2 & 0.5 & 50.3 & 0.2 & 0.3 & 51.2 & 0.3 & 0.6 \\
\hline & 90 days & 61.1 & 0.3 & 0.6 & 58.5 & 0.4 & 0.7 & 60.6 & 0.2 & 0.3 \\
\hline \multirow{2}{*}{$\begin{array}{l}\text { Flexural strength } \\
(\mathrm{MPa})\end{array}$} & 2 & 4.8 & 0.0 & 1.0 & 4.9 & 0.2 & 4. & 5.0 & 0.0 & 0.9 \\
\hline & 90 days & 5.8 & 0.1 & 2.4 & 6.1 & 0.1 & 2.3 & 6.3 & 0.1 & 2.0 \\
\hline \multirow{2}{*}{$\begin{array}{l}\text { Tensile strength of } \\
\text { surface layers (MPa) }\end{array}$} & $28 \mathrm{da}$ & 2.59 & 0.12 & 4.56 & 2.28 & 0.13 & 5.47 & 2.93 & 0.25 & 8.39 \\
\hline & 90 days & 2.76 & 0.08 & 2.92 & 2.55 & 0.12 & 4.16 & 3.31 & 0.26 & 7.78 \\
\hline
\end{tabular}

Note: SD-Standard deviation, $\mathrm{CV}$-coefficient of variation (\%).

Table 18. Results of the durability parameters of tested fiber concretes.

\begin{tabular}{|c|c|c|c|c|c|c|c|c|c|c|}
\hline \multirow{2}{*}{\multicolumn{2}{|c|}{ Parameter/Designation }} & \multicolumn{3}{|c|}{ PSM-L } & \multicolumn{3}{|c|}{ PSM-PM } & \multicolumn{3}{|c|}{ PSM-BF } \\
\hline & & \multicolumn{2}{|c|}{ Mean SD } & \multirow{2}{*}{$\begin{array}{c}\text { CV } \\
4\end{array}$} & \multicolumn{2}{|c|}{ Mean SD } & \multirow{2}{*}{$\begin{array}{c}\text { CV } \\
3\end{array}$} & \multicolumn{2}{|c|}{ Mean SD } & \multirow{2}{*}{$\begin{array}{c}\mathrm{CV} \\
8\end{array}$} \\
\hline & 28 days & 22 & 1 & & 19 & 0 & & 20 & 2 & \\
\hline Concrete watertightness (mm) & 90 days & 16 & 1.7 & 10.9 & 15 & 0.5 & 3.1 & 15 & 1.2 & 8.1 \\
\hline \multirow{2}{*}{ Water absorption (\%) } & $28 \mathrm{da}$ & 5.3 & 0.2 & 3.0 & 6.2 & 0.1 & 1.3 & 5.4 & 0.1 & 2.6 \\
\hline & 90 days & 5.2 & 0.1 & 1.6 & 5.9 & 0.1 & 1.4 & 5.3 & 0.2 & 3.2 \\
\hline \multirow{2}{*}{$\begin{array}{l}\text { Determination of abrasion in } \\
\text { accordance with EN } 13892-3 \\
\qquad\left(\mathrm{~cm}^{3} / 50 \mathrm{~cm}^{3}\right)\end{array}$} & $28 \mathrm{da}$ & 12.95 & 0.29 & 2.24 & 11.95 & 0.17 & 1.42 & 10.25 & 0.11 & 1.05 \\
\hline & 90 days & 11.35 & 0.09 & 0.75 & 10.10 & 0.10 & 1.02 & 9.65 & 0.06 & 0.65 \\
\hline \multirow{2}{*}{$\begin{array}{l}\text { Determination of concrete } \\
\text { abrasion in accordance with } \\
\text { CSN } 731324(\%)\end{array}$} & 28 days & 4.90 & 0.22 & 4.41 & 4.40 & 0.22 & 4.91 & 4.50 & 0.08 & 1.81 \\
\hline & 90 days & 4.00 & 0.21 & 5.14 & 3.80 & 0.13 & 3.28 & 3.70 & 0.05 & 1.27 \\
\hline
\end{tabular}

Note: SD—Standard deviation, CV—coefficient of variation.

\subsection{Discussion of Results}

The results of mechanical parameters when using fibers point to a significant increase in tensile strength of surface layers of concrete when using basalt fibers. As expected, this positive effect was not observed for polypropylene fibers. It can be concluded that these values show a connection with the tensile strength of the individual fibers, where basalt fibers significantly exceed the tensile strength of polymer fibers. For the remaining mechanical parameters of produced concretes, it is clear that the addition of fibers has no positive effect on the compressive strength or flexural strength, although in this experiment a slight increase in the second named parameter could be observed following the addition of fibers. From the point of view of the watertightness of concrete, again virtually no effect of the addition of fibers can be observed. The water absorption of concrete with the addition of polymer 
fibers was slightly increased compared to concrete without fibers and with basalt fibers. This fact can be attributed to the theory regarding many experiments performed that the addition of microfibers can introduce air into the concrete during mixing, which adheres to the fibers and can then degrade some mechanical, physical or durability parameters of the composite [51].

In the case of the resistance of concrete to mechanical abrasion, a significant difference between the value after 28 and 90 days could be observed again. These results correspond to the conclusions from the previous part of the experiment regarding the use of mineral additives. In terms of influencing the resistance of concrete to mechanical abrasion through the addition of fibers, their positive effect can be observed in the case of the use of polymer and basalt fibers. The resistance of concrete to mechanical abrasion was more significantly affected by basalt fibers, which may again be related to their noticeably better mechanical parameters compared to polymer fibers. However, it was necessary to further investigate by means of further experiments whether this positive effect by the addition of basalt fibers relates only to the resistance to mechanical abrasion tested with the Böhm's device or whether the state would be the same, for example when testing with flowing liquids or cavitation. The following Figures 10 and 11 again show individual parameters of concrete and its resistance to mechanical abrasion.

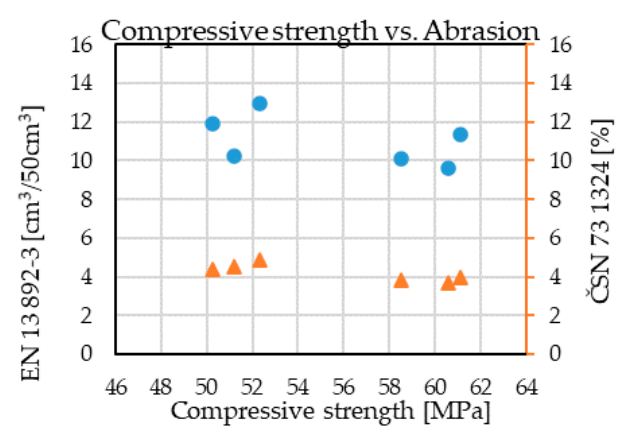

(a) •EN 13 892-3 $\mathbf{\Delta}$ CSN 731327

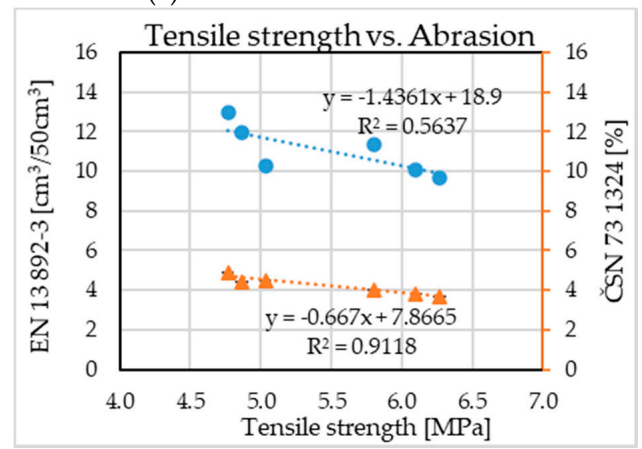

(b) • EN 13 892-3 $\Delta$ CSN 731327

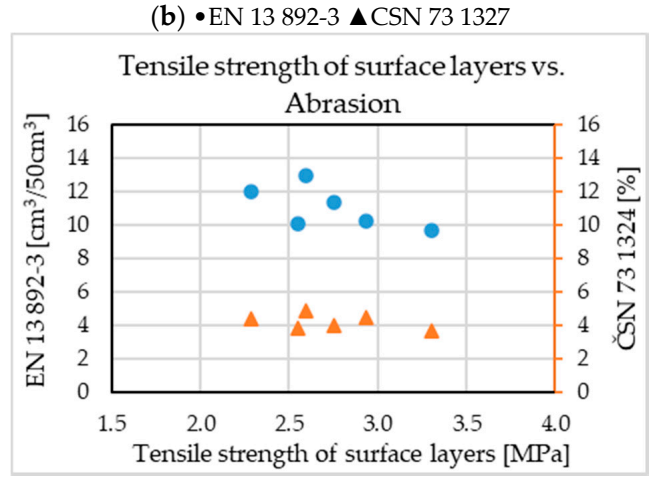

(c) •EN 13 892-3 $\Delta$ CSN 731327

Figure 10. Mechanical parameters of produced fiber concretes and their resistance to mechanical abrasion: (a) Compressive strength; (b) Tensile strength; (c) Tensile strength of surface layers. 


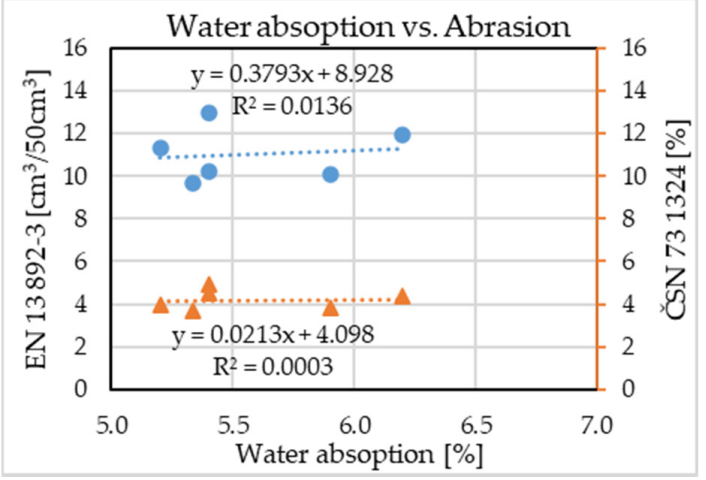

(a) •EN 13 892-3 $\Delta$ ČSN 731327

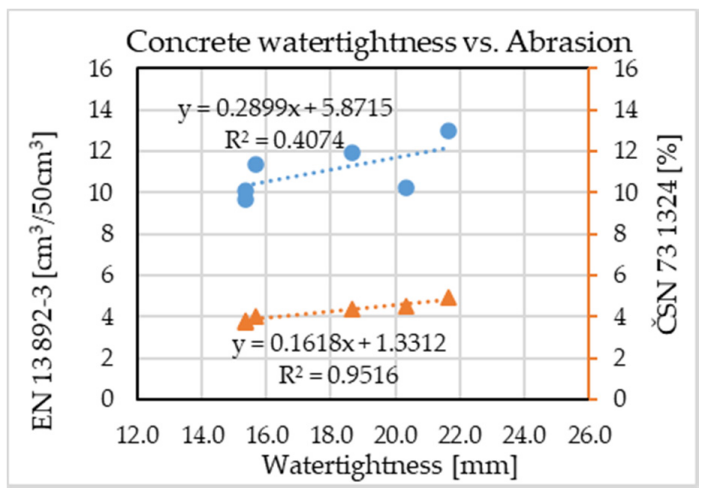

(b) •EN 13 892-3 $\Delta$ ČSN 731327

Figure 11. Durability parameters of produced fiber concretes and their resistance to mechanical abrasion: (a) Water absorption; (b) Concrete watertightness.

Significant dependences on the resistance to mechanical abrasion can be seen in the graphical dependences of some parameters of the produced fiber concretes. These parameters mainly include tensile strength. The level of dependence of all tested parameters of produced fiber concretes was further assessed using Pearson's correlation coefficient. The results are provided in Table 19.

Table 19. Pearson's correlation coefficient results.

\begin{tabular}{cccc}
\hline \multicolumn{2}{c}{ Parameter/Designation } & CSN 73 1324 & EN 13 892-3 \\
\hline \multirow{2}{*}{ Compressive strength } & 28 days & 0.96 & 0.42 \\
& 90 days & 0.36 & 0.43 \\
Flexural strength & 28 days & -0.76 & -0.99 \\
Tensile strength of & 90 days & -1.00 & -0.99 \\
surface layers & 28 days & 0.16 & -0.64 \\
Concrete watertightness & 90 days & -0.55 & -0.49 \\
& 28 days & 0.99 & 0.54 \\
Water absorption & 90 days & 0.94 & 0.97 \\
& 28 days & -0.73 & 0.05 \\
& 90 days & -0.32 & -0.39 \\
\hline
\end{tabular}

In the case of the addition of fibers, it was also possible to prove that a significant dependence between the watertightness of the concrete and the tensile strength can be seen in terms of the resistance of the concrete to mechanical abrasion. The results confirmed the impact of mineral additives on the resistance of concrete to mechanical abrasion at the time determined in the previous part of the experiment and further provided a picture of the positive effect of the resistance of the composite to mechanical abrasion using dispersed fibers. It has been proven that the resistance of the composite was significantly increased by basalt fibers and this increase was up to $8 \%$ after 28 and 90 days of maturation. In summary:

- The addition of fibers in the form of dispersed reinforcement has a direct impact on increasing the value of the water-cement ratio

- Basalt dispersed fibers have a positive effect on the tensile strength of the surface layers of concrete

- The addition of polymer and basalt dispersed fibers does not have a significant positive impact on the mechanical parameters of the composite, except for on the tensile strength of the surface layers of concrete

- The addition of flexible fibers of dispersed reinforcement (polymer and basalt) has a positive impact on the resistance of the composite to mechanical abrasion. 


\section{Discussion of the Experiment}

The results of the experiment clearly determine the dependence of the type of aggregate used on the subsequent resistance of the composite to mechanical abrasion. It is clear from the results that the value of crush resistance using the Los Angeles method of a given aggregate greatly contributes to the resistance of the resulting composite. The dependence of the value of concrete resistance to mechanical abrasion after 28 days of standard maturing is practically linear with the value of the resistance of the given aggregate to crushing when using the Los Angeles method. However, this dependence disappears with a longer period of maturation of the composite and based on the results, it can be stated that the used aggregate is not a decisive parameter for the resistance of the composite to mechanical abrasion after 90 days of standard maturation. The conclusions of this part of the experiment provide an insight into the possible design of concrete for the XM environment regarding the construction time and their exposure to abrasion wear. For concretes, their exposure to abrasion wear occurs with a longer time horizon, meaning there is no need to use economically demanding and ecologically unsuitable aggregates of an igneous character, the occurrence of which is limited in many countries.

In the second part of the experiment, the influence of individual types of mineral additives on the resistance of concrete to mechanical abrasion was determined. Already during the analysis of the mineral additives themselves, it was shown that finely ground limestone is not a completely inert additive and can participate in the hydration process of cement. In the very core of the experiment, when verifying the impact of individual types of mineral additives on the abrasion resistance of concrete, it was clearly shown that the positive effect of their addition was noticeable prior to a longer time horizon. In the early stage of maturation of the composite, the used aggregate mainly contributed to its resistance to mechanical abrasion, but already after 90 days of maturation, the differences in the use of individual types of aggregates or mineral additives disappeared considerably. Thanks to these results, it can be stated that the addition of mineral additives has a positive impact on the resistance of concrete to mechanical abrasion with a longer time horizon. The results also showed that it is not entirely justified to use economically demanding and not readily available active additives such as microsilica, but the use of secondary raw materials such as high-temperature fly ash or very finely ground limestone, which is considered to be inert by legislation, seems appropriate. With the addition of mineral additives while maintaining the consistency and compressive strength after 28 days of standard maturing, the resistance of the concrete to abrasion at an early stage of maturing may deteriorate. This may be due to the slow progression of some pozzolanic reactions, but also due to the increase in binder content costing aggregate, which has been shown to be a major carrier of its resistance to mechanical abrasion at an early stage of composite maturation. For a longer maturing period, the use of mineral additives to improve the abrasion resistance of the concrete seems appropriate.

The last part of the experiment was focused on determining the effect of the addition of dispersed reinforcement on the resistance of the composite to mechanical abrasion. Polymer fibers and basalt fibers were used for this experiment in the dosage proposed by the manufacturers. The results show a different influence of individual types of fibers, which was probably due to their mechanical parameters. In general, however, it can be stated that the addition of fibers in the form of dispersed reinforcement can have a positive effect on the resistance of the composite to mechanical abrasion. For basalt fibers, this improvement was the same after 28 and 90 days of standard maturation and amounted to about $8 \%$. Therefore, the use of fibers to improve the resistance of concrete to mechanical abrasion cannot be unequivocally recommended unless their presence positively affects some other parameter of the composite, such as the elimination of volume changes or the resistance to high temperatures.

It has been shown that the type of aggregate used has a significant impact on the resistance of the composite to mechanical abrasion at an early stage of its maturation. This effect was practically linearly associated with the resistance to crushing using the Los Angeles method. A very significant dependence was observed in the whole experiment between the watertightness of concrete, or its flexural strength and its resistance to mechanical abrasion. The use of mineral additives as a component of concrete, which positively affects its resistance to mechanical abrasion, is suitable for a longer 
maturing period. After 90 days of maturing, the positive impact of the use of mineral additives on the mechanical and durability parameters of concrete was observed. Simultaneously, however, no significant difference was observed between the impact of the use of some economically demanding additives, such as microsilica, and very finely ground limestone, which is classified as an inert additive. The addition of fibers in the form of dispersed reinforcement can further help to increase the resistance of concrete to mechanical abrasion. This positive effect can be observed after 28 and 90 days and in both cases, it is practically the same effect.

\section{Conclusions}

Through comprehensive research, the impact of the type of aggregate used, mineral additives and the subsequent addition of fibers on the resistance of concrete to mechanical abrasion was gradually monitored. Thanks to this experiment, it was possible to clearly demonstrate how the individual input raw materials not only affect the mechanical parameters of the composite, but also the selected durability parameters, specifically the resistance to mechanical abrasion. The following findings can be summarized from the results of the performed experiment:

- Crushed aggregate with a larger measuring surface allows better connection in the transit zone between cement stone and aggregate, which is related to higher results of the flexural strength and tensile strength of surface layers of concrete.

- The higher abrasion resistance of concrete is related to a lower water absorption of aggregate and their better resistance of aggregate to crushing when using the Los Angeles method.

- It was found that the quality of aggregate plays the most important role in terms of the resistance of concrete to abrasion in the early stages of maturing and with a longer period of time, its function mainly becomes dependent on the properties of the cement matrix itself.

- It was proven that a positive increase of the wear resistance of concrete by $9 \%$ occurs in a longer period of concrete maturing when using the active additives involved in the hydration process.

- Both types of fibers improve the wear resistance of concrete. This effect was more significant when using basalt fibers, which increase the wear resistance of concrete by $8 \%$ in comparison with reference samples without fibers.

Although insufficient attention is still paid today to concretes intended for exposure class XM (according CSN EN 73 2402/Z1), it is clear that almost every concrete structure encounters a type of wear through abrasion. The most susceptible types to this type of wear are constructions which are directly used for walking or running, or which are in direct contact with, for example, a flowing liquid medium. Concrete designs, especially for these types of structures (traffic and water management structures), should be based directly on defined parameters.

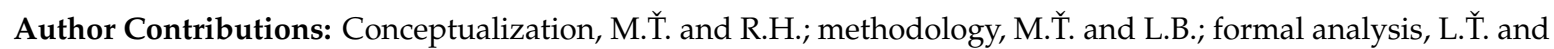

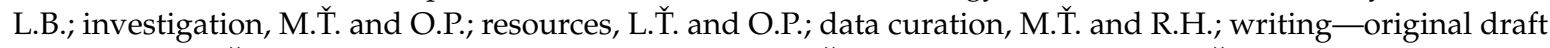
preparation, M.Ť. and L.B.; writing—review and editing, L.ك̌. and R.H.; visualization, L.̌̌.; supervision, R.H. and L.B.; project administration, L.S. and L.B.; funding acquisition, L.S. and L.B. All authors have read and agreed to the published version of the manuscript.

Funding: This research was funded by the Czech Science Foundation, grant number GA 18-25035S.

Acknowledgments: This outcome has been achieved with the financial support of the project GA 18-25035S "Study and subsequent modelling of mechanical corrosion of cementitious composites exposed to flowing fluids".

Conflicts of Interest: The authors declare no conflict of interest.

\section{References}

1. EN 206+A1. Concrete: Specification, Performance, Production and Conformity; European Committee for Standardization: Brussels, Belgium, 2018.

2. CSN P 73 2404/Z1. Beton—Specifikace, Vlastnosti, Výroba a Shoda—Doplňující Informace; Česká Agentura Pro Standardizaci: Praha, Česká Republika, 2018. 
3. EN 1990. Eurocode: Basis of Structural Design; European Committee for Standardization: Brussels, Belgium, 2010.

4. Adamiak, M. Abrasion Resistance of Materials, 1st ed.; InTech: Rijeka, Croatia, 2012; pp. 187-199. ISBN 9535103008. [CrossRef]

5. Dugarte, M.; Martinez-Arguelles, G.; Torres, J. Experimental Evaluation of Modified Sulfur Concrete for Achieving Sustainability in Industry Applications. Sustainability 2019, 11, 70. [CrossRef]

6. Scott, B.; Safiuddin, M. Abrasion Resistance of Concrete-Design, Construction and Case Study. Chall. J. Concr. Res. Lett. 2015, 6, 136-148.

7. Van Dam, E.J. Abrasion Resistance of Concrete and the Use of High Performance Concrete for Concrete Railway Crossties. Master's Thesis, University of Illinois, Urbana-Champaign, IL, USA, 2014.

8. Yu-Wen, L. Improving the abrasion resistance of hydraulic-concrete containing surface crack by adding silica fume. Constr. Build. Mater. 2007, 21, 972-977. [CrossRef]

9. Horszczaruk, E. Abrasion resistance of high-strength concrete in hydraulic structures. Wear 2005, 259,'62-69. [CrossRef]

10. Ramesh Kumar, G.B.; Kumar Sharma, U.; Bhardwaj, A. Influence of various material parameters on the abrasion resistance of concrete by sand blasting. J. Asian Concr. Fed. 2017, 3, 35-48. [CrossRef]

11. Tazawa, E. Autogenous Shrinkage of Concrete, 1st ed.; CRC Press: Boca Raton, FL, USA, 1999; pp. $195-201$. ISBN 9780429079382.

12. Briatka, P.; Makýš, P.; Gašparík, J. A Prolongation of the Service Life of Cement-Based Composites by Controlling the Development of Their Strength and Volume Changes. Sustainability 2020, 12, 8479. [CrossRef]

13. Osuska, L.; Tazky, M.; Hela, R. High-Performance Cement Composite for Architectural Elements with Elimination of Micro Cracks. Int. J. Eng. Technol. 2019, 11, 101-104. [CrossRef]

14. Wu, Z.; Mac, M.J.; Wong, H.S.; Buenfeld, N.R. Characterization of Microcracks and Influence on Transport Properties. In Proceedings of the TRANSCEND Conference, Guilford, CT, USA, 3-6 November 2013; NANOCEM: Lousanne, Switzerland, 2013.

15. Shengxing, W.; Xudong, C.; Jikai, Z.-H. Influence of strain rate and water content on mechanical behaviour of dam concrete. Constr. Build. Mater. 2012, 36, 448-457. [CrossRef]

16. EN 12 620+A1. Aggregates for Concrete; European Committee for Standardization: Brussels, Belgium, 2008.

17. EN 13 242+A1. Aggregates for Unbound and Hydraulically Bound Materials for Use in Civil Engineering Work and Road Construction; European Committee for Standardization: Brussels, Belgium, 2008.

18. EN 1097-2. Tests for Mechanical and Physical Properties of Aggregates_Part 2: Methods for the Determination of Resistance to Fragmentation; European Committee for Standardization: Brussels, Belgium, 2020.

19. EN 1097-6. Tests for Mechanical and Physical Properties of Aggregates_Part 6: Determination of Particle Density and Water Absorption; European Committee for Standardization: Brussels, Belgium, 2013.

20. EN 933-1. Tests for Geometrical Properties of Aggregates-Part 1: Determination of Particle Size Distribution: Sieving Method; European Committee for Standardization: Brussels, Belgium, 2012.

21. EN 933-4. Tests for Geometrical Properties of Aggregates-Part 4: Determination of Particle Shape. Shape Index; European Committee for Standardization: Brussels, Belgium, 2008.

22. Scrivener, K.L.; Crumbie, A.K.; Laugesen, P. The Interfacial Transition Zone (ITZ) Between Cement Paste and Aggregate in Concrete. Interface Sci. 2004, 12, 411-421. [CrossRef]

23. Popovics, S. Strength and Related Properties of Concrete: A Quantitative Approach, 1st ed.; John Wiley \& Sons: Hoboken, NJ, USA, 1998; pp. 299-300. ISBN 9780471149033.

24. Papenfus, N.J. Abrasion Wear, Abrasion, Resistance, and Related Strength Characteristics in Concrete, with Special Reference to Concrete Pavers. Ph.D. Thesis, University of Witwatersrand, Johannesburg, South Africa, 2002; pp. 139-144.

25. EN 12 350-2. Testing Fresh Concrete-Part 2: Slump-Test; European Committee for Standardization: Brussels, Belgium, 2020.

26. EN 12 350-6. Testing Fresh Concrete-Part 6: Density; European Committee for Standardization: Brussels, Belgium, 2019.

27. EN 12 390-3. Testing Hardened Concrete-Part 3: Compressive Strength of Test Specimens; European Committee for Standardization: Brussels, Belgium, 2020.

28. EN 12 390-5. Testing Hardened Concrete-Part 5: Flexural Strength of Test Specimens; European Committee for Standardization: Brussels, Belgium, 2019. 
29. CSN 73 1318. Stanovení Pevnosti Betonu v Tahu; Úřad Pro Technickou Normalizaci Metrologii a Státní Zkušebnictví: Praha, Česká Republika, 1987. (In Czech)

30. EN 12 390-6. Testing Hardened Concrete_Part 6: Tensile Splitting Strength of Test Specimens; European Committee for Standardization: Brussels, Belgium, 2010.

31. ̌̌VC. Technické Kvalitativní Podminky Staveb ǨVC ČR, Kapitola 1-Provádění Betonových a Zelezobetonových Konstrukcí; ̌̌editelství Vodních Cest ČR: Praha, Česká Republika, 2009. (In Czech)

32. ČSN 73 1316. Stanovení Vlhkosti, Nasákavosti a Vzlínavosti Betonu; Úřad Pro Technickou Normalizaci, Metrologii a Státní Zkušebnictví: Praha, Česká Republika, 1990. (In Czech)

33. ČSN 73 1324. Stanovení Obrusnosti Betonu; Úřad Pro Technickou Normalizaci, Metrologii a Státní Zkušebnictví: Praha, Česká Republika, 1972. (In Czech)

34. EN 13 892-3. Methods of Test for Screed Materials-Part 3: Determination of Wear Resistance-Böhme; European Committee for Standardization: Brussels, Belgium, 2015.

35. Glen, S. Correlation Coefficient: Simple Definition, Formula, Easy Steps. StatisticsHowTo.com. Available online: https://www.statisticshowto.com/probability-and-statistics/correlation-coefficient-formula/ (accessed on 3 August 2020).

36. Rodríguez-Roblero, M.J.; Ayon, J.J.; Cascante, G.; Pandey, M.D.; Alyousef, R.; Topper, T. Application of correlation analysis techniques to surface wave testing for the evaluation of reinforced concrete structural elements. NDT E Int. 2019, 102, 68-76. [CrossRef]

37. Yazıc1, S.; İnan, G. An investigation on the wear resistance of high strength concretes. Wear 2006, 260, 615-618. [CrossRef]

38. Tazky, M.; Hela, R. Development of Structural Concrete with Fly Ash-Mixing of Different Particle- Size Fractions of Fly Ash and Cement. In Fly Ash—Properties, Analysis and Performance, 1st ed.; Nova Publisher: New York, NY, USA, 2017; pp. 219-236. ISBN 9781536105162.

39. Ma, L.G.; Zhang, Y.S. Study on the Effect of Fly Ash or Silica Fume to Hydration Heat of Cement. Adv. Mater. Res. 2011, 250-253, 4001-4004. [CrossRef]

40. Hela, R.; Tazky, M.; Bodnarova, L. Possibilities of Determination of Optimal Dosage of Power Plant Fly Ash for Concrete. J. Teknol. 2016, 78, 59-64. [CrossRef]

41. Mohamed, A.R.; Elsalamawy, M.; Ragab, R. Modeling the influence of limestone addition on cement hydration. Alexandria Eng. J. 2015, 54, 1-5. [CrossRef]

42. Zhou, W.; Li, L.; Liu, S.H.; Vinh, T.D.; Liu, X.H. Hydration properties and thermal analysis of cement-based materials containing limestone powder. J. Cent. South Univ. 2017, 24, 2932-2939. [CrossRef]

43. Grdic, Z.J.; Gordana, A.; Toplicic, C.; Ristic, N.S.; Destopovic, I.M. Abrasion resistance of concrete micro-reinforced with polypropylene fibers. Constr. Build. Mater. 2012, 27, 305-312. [CrossRef]

44. Bodnarova, L.; Hosko, M.; Martinec, P. Methods of Testing the Properties of Fibre-Cement Composites. In Proceedings of the IOP Conference Series: Materials Science and Engineering, Herlany, Slovakia, 13-15 June 2018; pp. 1-7. [CrossRef]

45. Ristic, N.; Toplicic-Curcic, G.; Grdic, D. Abrasion resistance of concrete made with micro fibers and recycled granulated rubber. Zast. Mater. 2016, 56, 435-445. [CrossRef]

46. Sadowska-Buraczewska, B.; Szafraniec, M.; Barnat-Hunek, D.; Łagód, G. Flexural Behavior of Composite Concrete Slabs Made with Steel and Polypropylene Fibers Reinforced Concrete in the Compression Zone. Materials 2020, 13, 3616. [CrossRef]

47. Barnat-Hunek, D.; Góra, J.; Andrzejuk, W.; Łagód, G. The Microstructure-Mechanical Properties of Hybrid Fibres-Reinforced Self-Compacting Lightweight Concrete with Perlite Aggregate. Materials 2018, 11, 1093. [CrossRef]

48. Jarolim, T.; Hela, R.; Labaj, M. Influence of the Amount of Dispersed Suspension of Carbon Nano-Tubes on Physico- Mechanical Properties of Cement Mortar. In Advanced Materials Research; Trans Tech Publications: Stafa-Zurich, Switzerland, 2015; pp. 65-68. [CrossRef]

49. Liu, Y.W.; Lin, Y.Y.; Cho, S.W. Abrasion Behavior of Steel-Fiber-Reinforced Concrete in Hydraulic Structures. Appl. Sci. 2020, 10, 5562. [CrossRef] 
50. Hussain, I.; Ali, B.; Akhtar, T.; Jameel, M.S.; Raza, S.S. Comparison of mechanical properties of concrete and design thickness of pavement with different types of fiber-reinforcements (steel, glass, and polypropylene). Case Stud. Constr. Mater. 2020, 13, e00429. [CrossRef]

51. Babaie, R.; Abolfazli, M.; Fahimifar, A. Mechanical properties of steel and polymer fiber reinforced concrete. J. Mech. Behav. Mater. 2019, 28, 119-134. [CrossRef]

Publisher's Note: MDPI stays neutral with regard to jurisdictional claims in published maps and institutional affiliations.

(C) 2020 by the authors. Licensee MDPI, Basel, Switzerland. This article is an open access article distributed under the terms and conditions of the Creative Commons Attribution (CC BY) license (http://creativecommons.org/licenses/by/4.0/). 